\title{
Proline to Threonine Mutation at Position 162 of NS5B of Classical Swine Fever Virus Vaccine C Strain Promoted Genome Replication and Infectious Virus Production by Facilitating Initiation of RNA Synthesis
}

\author{
Huining Pang, Ling Li, Hongru Liu and Zishu Pan *
}

check for updates

Citation: Pang, H.; Li, L.; Liu, H.; Pan, Z. Proline to Threonine Mutation at Position 162 of NS5B of Classical Swine Fever Virus Vaccine C Strain Promoted Genome Replication and Infectious Virus Production by Facilitating Initiation of RNA Synthesis. Viruses 2021, 13, 1523. https://doi.org/10.3390/v13081523

Academic Editor: Daniel L. Rock

Received: 11 May 2021

Accepted: 30 July 2021

Published: 2 August 2021

Publisher's Note: MDPI stays neutral with regard to jurisdictional claims in published maps and institutional affiliations.

Copyright: (c) 2021 by the authors. Licensee MDPI, Basel, Switzerland. This article is an open access article distributed under the terms and conditions of the Creative Commons Attribution (CC BY) license (https:// creativecommons.org/licenses/by/ $4.0 /)$.
State Key Laboratory of Virology, College of Life Sciences, Wuhan University, Wuhan 430072, China; phn@whu.edu.cn (H.P.); concentrate1@aliyun.com (L.L.); 2019202040043@whu.edu.cn (H.L.)

* Correspondence: zspan@whu.edu.cn

\begin{abstract}
The 3'untranslated region (3'UTR) and NS5B of classical swine fever virus (CSFV) play vital roles in viral genome replication. In this study, two chimeric viruses, $\mathrm{vC} / \mathrm{SM} 3^{\prime} \mathrm{UTR}$ and $\mathrm{vC} / \mathrm{b3}^{\prime} \mathrm{UTR}$, with $3^{\prime} \mathrm{UTR}$ substitution of CSFV Shimen strain or bovine viral diarrhea virus (BVDV) NADL strain, were constructed based on the infectious cDNA clone of CSFV vaccine C strain, respectively. After virus rescue, each recombinant chimeric virus was subjected to continuous passages in PK-15 cells. The representative passaged viruses were characterized and sequenced. Serial passages resulted in generation of mutations and the passaged viruses exhibited significantly increased genomic replication efficiency and infectious virus production compared to parent viruses. A proline to threonine mutation at position 162 of NS5B was identified in both passaged vC/SM3'UTR and $\mathrm{vC} / \mathrm{b3}^{\prime} \mathrm{UTR}$. We generated P162T mutants of two chimeras using the reverse genetics system, separately. The single P162T mutation in NS5B of vC/SM3' UTR or $\mathrm{vC} / \mathrm{b3}^{\prime} \mathrm{UTR}$ played a key role in increased viral genome replication and infectious virus production. The P162T mutation increased $\mathrm{vC} \mathrm{SM}^{\prime} \mathrm{UTR}_{\mathrm{P} 162 \mathrm{~T}}$ replication in rabbits. From RNA-dependent RNA polymerase (RdRp) assays in vitro, the NS5B containing P162T mutation (NS5B $\mathrm{P}_{\mathrm{P} 162 \mathrm{~T}}$ ) exhibited enhanced RdRp activity for different RNA templates. We further identified that the enhanced RdRp activity originated from increased initiation efficiency of RNA synthesis. These findings revealed a novel function for the NS5B residue 162 in modulating pestivirus replication.
\end{abstract}

Keywords: classical swine fever virus; 3'untranslated region; NS5B; RNA-dependent RNA polymerase; replication; initiation

\section{Introduction}

Classical swine fever virus (CSFV) is causative agent of an economically important, highly contagious disease of pigs. CSFV is an enveloped, single-stranded positive-sense RNA virus. CSFV belongs to the genus Pestivirus in the family Flaviviridae, along with bovine viral diarrhea virus (BVDV) and border disease virus (BDV) [1]. The CSFV genome is approximately $12.3 \mathrm{~kb}$ containing one large open reading frame (ORF) flanked by two untranslated regions (5'UTR and $3^{\prime}$ UTR) [2,3]. The ORF encodes a polyprotein of 3898 amino acids. The polyprotein is processed by cellular and viral proteases yielding 12 mature proteins: 4 structural proteins (Core, $\mathrm{E}^{\mathrm{rns}}, \mathrm{E} 1$ and E2) and 8 non-structural proteins (Npro, p7, NS2, NS3, NS4A, NS4B, NS5A and NS5B) [4-6].

CSFV $C$ strain is a lapinized live attenuated vaccine strain which was obtained by serial passages of a highly virulent CSFV strain in the rabbit in the 1950s [7,8]. CSFV C strain induces a typical fever response in the rabbit and a robust replication in the spleen of the rabbit [9]. The CSFV C strain is widely used as the live attenuated CSF vaccine and provides complete protection against virulent CSFV strains challenge [10-12]. 
The UTRs of CSFV are considered to be important elements for the translation and the replication of viral RNA [13,14], and also play an important role in the fever response in the rabbits induced by CSFV C strain [9]. The $3^{\prime} \mathrm{UTR}$ is proved to bind to NS5A and NS5B [15], and is probably involved in the initiation of the viral genome replication [16-19]. A 12-nt (CUUUUUUCUUUU) insertion existed in the $3^{\prime} U T R$ of CSFV C strain, not in other wild-type CSFV strains [20,21]. The 12-nt insertion contributes greatly to the decrease of virus titer [22].

NS5B, an RNA-dependent RNA polymerase (RdRp), is essential for replication of the viral RNA genome $[17,23,24]$. NS5B from the family Flaviviridae carries out RNA synthesis through a de novo initiation mechanism $[25,26]$. The RNA synthesis catalyzed by NS5B is divided into representative steps: apo state, initiation and elongation [27]. The initiation of RNA synthesis contains a rapid formation of initial dinucleotide and a rate-limiting formation of trinucleotide [28]. Then RNA synthesis transitions to a processive elongation mode with the NS5B conformation opening up [29]. The crystal structure analysis revealed that the overall fold of CSFV NS5B contains the typical polymerase finger, palm, thumb domains and an additional N-terminal domain (NTD) [30,31]. A characteristic conserved Gly-Asp-Asp (GDD) motif of NS5B was observed among RdRps from positive-strand RNA viruses [32,33]. The finger domain is composed of two sections of the amino acid sequence (residues 136 to 313 and residues 351 to 408), which has been identified to determine the preference of RNA templates [31]. The fingertip region containing the N-terminal part of the finger domain (residues 136 to 160) and an insertion in the $\beta$-finger domain (residues 260 to 288 ) is implicated in NTP binding and interaction with RNA template in BVDV NS5B [34,35].

In the present study, the $3^{\prime}$ UTR of CSFV C strain was substituted with $3^{\prime} \mathrm{UTR}$ of CSFV Shimen strain or BVDV NADL strain to generate $\mathrm{vC} / \mathrm{SM} 3^{\prime} \mathrm{UTR}$ and $\mathrm{vC} / \mathrm{b3}^{\prime} \mathrm{UTR}$, respectively. We investigated the characteristics of passaged viruses after serial passages. An adaptive Pro-to-Thr mutation (P162T) at position 162 of NS5B was identified in both the passaged $\mathrm{vC} / \mathrm{SM}^{\prime} \mathrm{UTR}$ and $\mathrm{vC} / \mathrm{b3}^{\prime} \mathrm{UTR}$. Site-mutated viruses were generated to investigate the influence of P162T mutation on viral replication and infectious virus production. The effect of P162T mutation on virus replication in the rabbits was also investigated. Wild-type NS5B protein (NS5B $\left.\mathrm{WT}_{\mathrm{WT}}\right)$ and its mutant $\left(\mathrm{NS5B}_{\mathrm{P} 162 \mathrm{~T}}\right)$ were expressed and purified to characterize the catalytic activity in RdRp assays in vitro. Our results indicated that the residue 162 of CSFV NS5B, an amino acid close to the fingertip region, plays a vital role in viral genome replication and infectious virus production by regulating the initiation efficiency of the RNA synthesis.

\section{Materials and Methods}

\subsection{Cells and Viruses}

Porcine kidney-15 (PK-15) cells, swine kidney-6 (SK-6) cells, and BVDV NADL strain were obtained from the China Center for Type Culture Collection (CCTCC, Wuhan, Hubei, China). The PK-15 and SK-6 cells were maintained at $37{ }^{\circ} \mathrm{C}$ with $5 \% \mathrm{CO}_{2}$ in Dulbecco's modified Eagle's medium (DMEM) (Invitrogen, Carlsbad, CA, USA) supplemented with 10\% fetal bovine serum (FBS) (Natocor, Cordoba, Argentina). The CSFV C strain was generated from a cDNA clone $\left(\mathrm{pSPT}_{\mathrm{I}} / \mathrm{C}\right)$ [36].

\subsection{Construction of Infectious Chimeric cDNA Clones and Rescue of Viruses}

Plasmid $\mathrm{pSPT}_{\mathrm{I}} / \mathrm{C}$, an infectious cDNA clone of CSFV C strain [36], was used to construct infectious chimeric cDNA clones containing CSFV Shimen strain or BVDV 3'UTR substitution. The $3^{\prime}$ UTR fragment of CSFV Shimen strain or BVDV was amplified by overlap extension PCR using specific primers (C11152-F/C12072-R and SM-3'UTR-F/SM3'UTR-R for Shimen 3'UTR, or C11152-F/C12072-R and NADL-3'UTR-F/NADL-3'UTR-R for BVDV $\left.3^{\prime} \mathrm{UTR}\right)$. The fragments were cloned into $\mathrm{PSPT}_{\mathrm{I}} / \mathrm{C}$ using the restriction enzymes Sph I and Mlu I to generate the infectious chimeric cDNA clones, $\mathrm{pSPT}_{\mathrm{I}} / \mathrm{C} / \mathrm{SM}^{\prime} \mathrm{UTR}^{\prime}$ and 
$\mathrm{pSPT}_{\mathrm{I}} / \mathrm{C} / \mathrm{b3}^{\prime} \mathrm{UTR}$, respectively. All constructs were sequenced to confirm their identities. The sequences of primers are listed in Table 1.

Table 1. Primers used in this study.

\begin{tabular}{ll}
\hline Primer & Sequence $\left(\mathbf{5}^{\prime} \mathbf{- 3}^{\prime}\right)$ \\
\hline C11152-F & GCAACAGCATGCTAAATGTC \\
C12072-R & CTCATGCCCCTCTCCCTATCAGC \\
SM-3'UTR-F & AGAGGGGCATGAGCGCGGGTAACCCG \\
SM-3'UTR-R & CGACGCGTCGGAGTACTGGTCGACCTCCGAAGTTGGGGGGGAGGGCCGTTAGGAAATTAC \\
NADL-3'UTR-F & GAGAGGGGCATGAGACAAAATGTATATATTG \\
NADL-3'UTR-R & CGACGCGTCGGAGTACTGGTCGACCTCCGAAGTTGGGGGGGAGGGGGCTGTTAGAGGTC \\
C9522-F & GACCCACTAGAAGTGAGAGATATG \\
C12047-R & CATCATCATGACTCTCAGCC \\
P162T-F & GGGCCCAGACAGACACAACCAACTTCCACCAAGCAA \\
P162T-R & GTGGAAGTGGTTGTGTCTGTGGGCCTAACCA \\
C-NS5B-F & AGGAGATATACCATGAGTAATGGGTGATGCAAGAAG \\
C-NS5B-R & CCGCTCGAGATTGTACCTGTCTGTCCCTTG \\
T7-F & TAGGAAGCAGCCCAGTAGTAG \\
T7-R & CATCACCCAATTACTCATGGTATATCTCCTTCTTAAAGTT \\
qRT-PCR-NS5B-F & ATCTGCCTACAAGGAAGTCATCGG \\
qRT-PCR-NS5B-R & CCAGTTGCCCTCTTTAACACCCATA \\
qRT-PCR-5'UTR-F & ATGCCCATAGTAGGACTAGCA \\
qRT-PCR-5'UTR-R & CTACTGACGACTGTCCTGTAC \\
CSFV-5'UTR-probe & 6FAM-TGGCGAGCTCCCTGGGTGGTCTAAGT-BHQ1 \\
T7-3'UTR-F & TAATACGACTCACTATAGGGCGCGGGTAACCCGGGATC \\
$3^{\prime} U T R-R$ & GGGCCGTTAGGAAATTACCTTAGTC \\
\hline
\end{tabular}

Virus rescue was performed as previously described [36]. Briefly, PK-15 cell monolayers in 6-well plates were transfected with $10 \mu \mathrm{L}$ of Lipofectamine ${ }^{\circledR} 2000$ (Invitrogen) and $2.5 \mu \mathrm{g}$ cDNA clone plasmid. The cell lysates were harvested by three cycles of freezing and thawing at $72 \mathrm{~h}$ post-transfection. After centrifugation at $5000 \times \mathrm{g}$ for $10 \mathrm{~min}$, the clarified supernatants were collected as the viral stocks and stored at $-80^{\circ} \mathrm{C}$ for subsequent assays. The viral stock was used to infect PK-15 cells to verify the recovery of infectious virus by immunofluorescence (IF) assay.

\subsection{Continuous Passaging of Chimeric Viruses, Virus Titration, Plaque Assay and Growth Curve}

The rescued chimeric virus aliquot $(200 \mu \mathrm{L})$ was used to infect $30 \mathrm{~mm}$ diameter plates seeded with PK-15 cells. At $72 \mathrm{~h}$ post-infection, $200 \mu \mathrm{L}$ culture fluid was transferred to a new plate containing PK-15 cells with $1.8 \mathrm{~mL}$ of culture medium. After every ten rounds of passages, the cell culture supernatant was collected and stored at $-80^{\circ} \mathrm{C}$. After sequencing, the virus stocks from 11th, 21st, and 31st passages (p11, p21 and p31) were used for subsequent assays.

For virus titration, a serial 10 -fold diluted viral stock in $100 \mu \mathrm{L}$ was added to PK-15 cells in $96-$ well plates. The cells were fixed with $50 \%(v / v)$ methanol/acetone at $72 \mathrm{~h}$ postinfection and stained with an anti-NS3 antibody for IF assay. Viral titers were calculated using the method of Reed and Muench [37], and expressed as $\mathrm{TCID}_{50} / \mathrm{mL}$.

Viral plaque assay was performed as previously described [38,39]. The SK-6 cell monolayers were infected at an MOI of 0.001 , washed twice with PBS at $1 \mathrm{~h}$ post-infection, overlaid with $2 \%$ FBS medium containing $1.5 \%$ methylcellulose, and incubated at $37^{\circ} \mathrm{C}$ for $96 \mathrm{~h}$. The overlay was then removed, the cells were fixed with $50 \%(v / v)$ methanol/acetone and stained by immunohistochemistry assay with an anti-NS3 antibody using Two-Step IHC Detection Reagent (ZSGB-BIO, Beijing, China).

To determine the one-step growth curve of virus, PK-15 cells were infected with viruses at an MOI of 0.001 in a 12-well plate [40]. After adsorption for $2 \mathrm{~h}$ at $37^{\circ} \mathrm{C}$, the overlay was replaced with fresh medium containing $2 \% \mathrm{FBS}$ and the cells were incubated at $37^{\circ} \mathrm{C}$. The viruses were harvested at indicated times and the viral titers were measured. 


\subsection{Immunofluorescence (IF) Assay}

Immunofluorescence staining was performed using an anti-NS3 antibody as previously described [41]. The cells were fixed with 50\% v/v methanol/acetone for $30 \mathrm{~min}$ at $-20{ }^{\circ} \mathrm{C}$ and blocked with $3 \%$ bovine serum albumin (BSA) (Biosharp, Hefei, Anhui, China) for $30 \mathrm{~min}$ at $37^{\circ} \mathrm{C}$. Primary antibody (anti-NS3) incubation was conducted for $90 \mathrm{~min}$ at $37^{\circ} \mathrm{C}$ with PBS containing $1 \%$ BSA, and secondary antibody (Alexa 488-conjugated goat anti-rabbit IgG, Jackson, West Grove, PA, USA) incubation was conducted for $60 \mathrm{~min}$ at $37^{\circ} \mathrm{C}$ with PBS containing $1 \%$ BSA.

\section{5. $q R T-P C R$}

Viral RNA copy number was measured by quantitative reverse transcription PCR (qRT-PCR). Briefly, PK-15 cell monolayers were infected with the virus at an indicated multiplicity of infection (MOI). Total RNA was extracted from the cells at 6, 12, and $24 \mathrm{~h}$ post-infection using an RNApure Kit (Aidlab, Beijing, China), and 700 ng of total RNA was reverse transcribed using TRUEscript RT MasterMix (Aidlab). Then, $2 \mu \mathrm{L}$ of cDNA was analyzed by qPCR using NovoStart ${ }^{\circledR}$ SYBR qPCR SuperMix Plus (Novoprotein, Shanghai, China) with the specific primers qRT-PCR-NS5B-F/ qRT-PCR-NS5B-R (Table 1). The data, presented as RNA copy number, were recorded from three independent experiments, and each experiment was performed in duplicate.

\subsection{Construction of Infectious Chimeric cDNA Clones Harbouring Site Mutation}

To construct the infectious clone of mutant $\mathrm{pSPT}_{\mathrm{I}} / \mathrm{C} / \mathrm{SM}^{\prime} \mathrm{UTR}_{\mathrm{P} 162 \mathrm{~T}}$ or $\mathrm{pSPT}_{\mathrm{I}} / \mathrm{C} /$ $\mathrm{b3}^{\prime} \mathrm{UTR}_{\mathrm{P} 162 \mathrm{~T}}$, the fragment containing C terminal of NS5A and NS5B region was amplified from $\mathrm{pSPT}_{\mathrm{I}} / \mathrm{C}$ using specific primers C9522-F/C12047-R (Table 1). Then, the fragment was cloned to pClone007 simple vector (Tsingke, Tianjin, China). The NS5B P162T mutation was introduced using specific primers P162T-F/P162T-R (Table 1) to produce pClone007$\mathrm{NS5B}_{\mathrm{P} 162 \mathrm{~T}}$ [42]. The fragment containing the P162T mutation in pClone007-NS5B $\mathrm{P}_{\mathrm{P} 162 \mathrm{~T}}$ was used to replace the counterpart of $\mathrm{pSPT}_{\mathrm{I}} / \mathrm{C} / \mathrm{SM}^{\prime} \mathrm{UTR}$ or $\mathrm{pSPT}_{\mathrm{I}} / \mathrm{C} / \mathrm{b3}^{\prime} \mathrm{UTR}$ using Xba I and Spe I. Both mutants were sequenced to confirm their identities. The mutated chimeric viruses were rescued and titrated.

\subsection{Experimental Infection of Rabbits}

The animal experiments were approved by the Institutional Animal Care and Use Committee of Wuhan University. Eight 14-week-old New Zealand White rabbits were divided into 3 groups and inoculated intravenously via the marginal ear vein with the $\mathrm{vC} / \mathrm{SM}^{\prime} \mathrm{UTR}, \mathrm{vC} / \mathrm{SM}^{\prime} \mathrm{UTR}_{\mathrm{P} 162 \mathrm{~T}}$ or DMEM, respectively. The rectal temperature of all rabbits was monitored every $6 \mathrm{~h}$ from 0 to $72 \mathrm{~h}$ post-infection to monitor the fever response. All rabbits were euthanized at 3 days post-inoculation [43]. The viral RNA copy numbers in the spleens of the rabbits were determined using qRT-PCR assay using the specific primers qRT-PCR-5'UTR-F/qRT-PCR-5'UTR-R and the probe CSFV-5'UTR-probe (Table 1) [44].

\subsection{Expression and Purification of NS5B and Its Mutant}

To prepare NS5B protein, the NS5B fragment with deletion of region encoding $24 \mathrm{C}$-terminal hydrophobic amino acids of CSFV C strain was amplified using primers C-NS5B-F/C-NS5B-R and T7-F/T7-R (Table 1), and then cloned into the expression plasmid pET28a. The P162T mutation was introduced using specific primers P162T-F/P162T-R (Table 1). Both constructs were confirmed by sequencing. Expression of NS5B and its mutant was performed as previously described $[45,46]$. Briefly, the constructs were transformed into Escherichia coli BL21-CodonPlus (DE3)-RIL strain, respectively, and cells were grown overnight at $37^{\circ} \mathrm{C}$ in the LB medium with $50 \mu \mathrm{g} / \mathrm{mL}$ kanamycin (KAN50) and $25 \mu \mathrm{g} / \mathrm{mL}$ chloramphenicol (CHL25). The overnight culture was inoculated into $1 \mathrm{~L}$ of LB medium with KAN50 and CHL25. The cells were grown at $37^{\circ} \mathrm{C}$ to an optical density of 0.6 at $600 \mathrm{~nm}$ and then were cooled to $20^{\circ} \mathrm{C}$, and isopropyl- $\beta$-D-thiogalactoside (IPTG) 
was added to a final concentration of $0.8 \mathrm{mM}$. After an additional $20 \mathrm{~h}$ incubation at $20{ }^{\circ} \mathrm{C}$, the cells were harvested by centrifugation and stored at $-80^{\circ} \mathrm{C}$ for subsequent assay.

The cells were resuspended in a lysis buffer containing $300 \mathrm{mM} \mathrm{NaCl}, 50 \mathrm{mM}$ Tris (pH8.0), $10 \mathrm{mM}$ imidazole, 20\% v/v glycerol, $1 \mathrm{U} / \mathrm{mL}$ DNase I, and $1 \times$ EDTA-free cocktail Protease Inhibitor (Yeason, Shanghai, China) and then were lysed by freezing and thawing followed by sonication. The lysate was clarified by centrifugation for $30 \mathrm{~min}$ at $15,000 \times g$ in a JLA-16.250 rotor (Beckman, Brea, CA, USA). The clarified lysate was loaded onto a HispurTM Ni-NTA Resin column (Thermo Scientific, Waltham, MA, USA). After washing with a wash buffer (300 mM NaCl, $50 \mathrm{mM}$ Tris (pH 8.0), $75 \mathrm{mM}$ imidazole, 20\% v/v glycerol), the protein was eluted with elution buffer ( $300 \mathrm{mM} \mathrm{NaCl}, 50 \mathrm{mM}$ Tris (pH 8.0), $250 \mathrm{mM}$ imidazole, 20\% v/v glycerol). Purified NS5B and its mutants were examined by SDS-PAGE. The fractions containing purified protein were pooled and dialyzed in $500 \mathrm{mM} \mathrm{NaCl}$, $50 \mathrm{mM}$ Tris (pH7.5), 20\% v/v glycerol, and $5 \mathrm{mM}$ dithiothreitol (DTT). The pooled fractions were then concentrated to approximately $120 \mu \mathrm{M}$, flash frozen with liquid nitrogen and stored at $-80^{\circ} \mathrm{C}$ in small aliquots.

\subsection{RNA Template Preparation}

The chemically synthesized 30-nt template strand (T30) purification, self-annealing, and annealing with a GG dinucleotide primer bearing a $5^{\prime}$-phosphate (P2) at a 1:1.25 molar ratio to yield the T30/P2 construct were performed as described previously [30]. The homopolymeric poly(C) RNA was purchased from Sigma (St. Louis, MO, USA). The 228-nt positive strand RNA of CSFV Shimen strain $3^{\prime} \mathrm{UTR}\left((+) \mathrm{CSFV} / 3^{\prime} \mathrm{UTR}\right)$ was transcribed in vitro using an amplified fragment from $\mathrm{PSPT}_{\mathrm{I}} / \mathrm{C} / \mathrm{SM}^{\prime} \mathrm{UTR}$ with specific primers T7-3'UTR-F/3'UTR-R (Table 1) and the transcripts were purified by $6 \%(w / v)$ polyacrylamide/7 M urea gel electrophoresis. The RNA was extracted using an RNApure Kit (Aidlab). The RNA concentration was measured using UV spectrophotometry and stored at $-80{ }^{\circ} \mathrm{C}$.

\subsection{RNA-Dependent RNA Polymerase (RdRp) Assay}

The de novo RdRp assay using T30 template was performed using the dinucleotide (P2)-driven reactions [30,47]. A $20 \mu \mathrm{L}$ reaction mixture containing $4 \mu \mathrm{M}$ T30/P2, $15 \mu \mathrm{M}$ extra P2, $6 \mu \mathrm{M}$ NS5B, $300 \mu \mathrm{M}$ ATP, $300 \mu \mathrm{M}$ UTP, $30 \mathrm{mM} \mathrm{NaCl}, 50 \mathrm{mM}$ Tris (pH7.0), $5 \mathrm{mM}$ $\mathrm{MgCl}_{2}$, and $5 \mathrm{mM}$ DTT was incubated at $30{ }^{\circ} \mathrm{C}$ for indicated times. For RdRp assays, reaction quenching, sample processing, denaturing polyacrylamide gel electrophoresis (PAGE) and RNA visualization by Stains-All (Sigma-Aldrich, St. Louis, MO, USA) staining were performed as previously described using the T30 template [48]. To quantify the intensity of 9-nt RNA product (P9), images of Stains-All based gels were taken with ChemiDoc MP (Bio-Rad, Hercules, CA, USA) and analyzed by Image Lab 5.2.1.

To evaluate the elongation activity of RdRp, a single-nucleotide elongation assay was performed as previously described [48]. Briefly, the reaction was performed in a two-step format. The reaction in the first step for 9-nt RNA synthesis proceeded for $50 \mathrm{~min}$, and the mixture was then centrifuged at $13,000 \times g$ for $1 \mathrm{~min}$. The pellet was harvested and washed twice by the reaction buffer ( $30 \mathrm{mM} \mathrm{NaCl}, 50 \mathrm{mM}$ Tris ( $\mathrm{pH} 7.0), 5 \mathrm{mM} \mathrm{MgCl}_{2}, 5 \mathrm{mM}$ DTT) and then resuspended in $18 \mu \mathrm{L}$ modified reaction buffer with $200 \mathrm{mM} \mathrm{NaCl}$. In the second step, $2 \mu \mathrm{L}$ CTP was supplemented to the resuspended mixture for a final concentration $300 \mu \mathrm{M}$ or $5 \mu \mathrm{M}$ to allow the single-nucleotide elongation at $30^{\circ} \mathrm{C}$, and the reaction was quenched immediately (" $0 \mathrm{~min}$ ") or after $1 \mathrm{~min}$. To accurately measure the reaction rate, an extra reaction was conducted at $0{ }^{\circ} \mathrm{C}$ under $5 \mu \mathrm{M}$ CTP and the reaction was quenched immediately (" $0 \mathrm{~s}$ ") or at $20 \mathrm{~s}, 40 \mathrm{~s}, 60 \mathrm{~s}$.

To evaluate the stability of elongation complex (EC), a high-salt (500 $\mathrm{mM} \mathrm{NaCl})$ incubation challenge was added into the single nucleotide elongation assay. The resuspended reaction mixture was incubated in the high-salt reaction buffer at $37{ }^{\circ} \mathrm{C}$ for indicated times $(0-72 \mathrm{~h})$, and then CTP was supplied at $300 \mu \mathrm{M}$ final concentration to trigger the P9-to-P10 conversion by P9-containing EC (EC9) that survived the incuba- 
tion. The reaction proceeded for $1 \mathrm{~min}$ at $30{ }^{\circ} \mathrm{C}$. After subtracting the intensity of the P10 misincorporation product $\left(\mathrm{P} 10_{\mathrm{m}}\right)$ from the first step, the intensity fraction of P10 $\left(\left[\mathrm{P} 10_{\text {int }}-\mathrm{P} 10_{\mathrm{m}, \text { int }}\right] /\left[\mathrm{P} 9_{\text {int }}+\mathrm{P} 10_{\text {int }}-\mathrm{P} 10_{\mathrm{m}, \text { int }}\right]\right)$ was used to calculate the fraction of the EC9 that survived the high-salt incubation. The fraction of P10 intensity value was fitted to one phase decay model to estimate the inactivation rate.

To test RdRp initiation efficiency, a P2 to the 3-nt product (P3) conversion assay was performed as previously described [47]. Briefly, ATP was supplied as the only NTP substrate and the final concentrations of ATP were 100, 200, 400, 800, and $1200 \mu \mathrm{M}$. A high P2:T30 ratio (20:1) was used for reaction to achieve multiple turnovers within a reasonable duration. The reactions were conducted at $30{ }^{\circ} \mathrm{C}$ for different times. Samples from the same mixture were loaded on different gels to normalize the intensities of product bands and the normalized intensity of $\mathrm{P} 3$ was then used to calculate the relative reaction rates that were fitted to the Michaelis-Menten equation.

Next, we further determined the RdRp activity for other RNA templates as previously described $[49,50]$. The accumulation of pyrophosphate (PPi) was measured during the RNA polymerization reaction using a phosphate-based colorimetric method with malachite green-molybdate as the color-developing reagent. The reactions were carried out in $25 \mu \mathrm{L}$ solution containing $2 \mu \mathrm{M}$ NS5B, $20 \mathrm{mM}$ Tris (pH7.5), $2.5 \mathrm{mM} \mathrm{MgCl}_{2}, 5 \mathrm{mM}$ DTT, $40 \mathrm{U} / \mathrm{mL}$ RNase Inhibitor, $20 \mathrm{U} / \mathrm{mL}$ thermostable pyrophosphatase (PPase), 20\% glycerol, $800 \mu \mathrm{M}$ GTP, and $500 \mathrm{ng}$ poly $(\mathrm{C})$ at $37^{\circ} \mathrm{C}$. For the template of $0.1 \mu \mathrm{M}(+) \mathrm{CSFV} / 3^{\prime} \mathrm{UTR}, 200 \mu \mathrm{M}$ NTPs were supplied as the substrate. The reactions were quenched by heating at $70{ }^{\circ} \mathrm{C}$ for $3 \mathrm{~min}$, where PPi was converted to two molecules of inorganic phosphate (Pi) by PPase simultaneously. The concentration of Pi was detected by mixing $10 \mu \mathrm{L}$ of the reaction mixture with $30 \mu \mathrm{L}$ Milli-Q water and $100 \mu \mathrm{L}$ of the malachite green-molybdate reagent. The phosphomolybdate complexes were measured by the absorbance at $630 \mathrm{~nm}$ by Multiskan MK3 (Thermo Scientific). The concentration of Pi was quantified using a phosphate standard curve obtained from 0 to $100 \mu \mathrm{M} \mathrm{NaH}{ }_{2} \mathrm{PO}_{4}$ solution.

\subsection{Statistical Analysis}

Statistical analyses of the data were performed using Student's $t$-test or one-way analysis of variance (ANOVA). A $p$-value less than 0.05 was considered significant.

\section{Results}

3.1. Rescue of Chimeric CSFV Vaccine C Strains Containing Pestivirus 3'UTR Substitution and Characteristics of Passaged Viruses

To investigate the influence of pestivirus $3^{\prime}$ UTR on viral characteristics and genome genetic stability, we substituted the $3^{\prime}$ UTR of CSFV vaccine C strain with $3^{\prime}$ UTR from CSFV Shimen strain or BVDV NADL strain to generate two chimeric infectious cDNA clones, $\mathrm{pSPT}_{\mathrm{I}} / \mathrm{C} / \mathrm{SM}^{\prime} \mathrm{UTR}$ and $\mathrm{pSPT} \mathrm{I}_{\mathrm{I}} / \mathrm{C} / \mathrm{b3}^{\prime} \mathrm{UTR}$, and the chimeric viruses $\mathrm{VC} / \mathrm{SM}^{\prime} \mathrm{UTR}$ and $\mathrm{vC} / \mathrm{b} 3^{\prime} \mathrm{UTR}$ were rescued from chimeric infectious cDNA clones, respectively (Figure 1a). The culture supernatants collected at $72 \mathrm{~h}$ post-transfection were used to infect PK-15 cells. After incubation of $24 \mathrm{~h}$, the infected PK-15 cells were assessed by IF assay using an antiNS3 antibody for detection of viral protein expression (Figure 1b). Data showed that the infectious viruses, $\mathrm{vC} / \mathrm{SM}^{\prime} \mathrm{UTR}$ and $\mathrm{vC} / \mathrm{b3}^{\prime} \mathrm{UTR}$, were successfully obtained.

Next, the rescued $\mathrm{vC} / \mathrm{SM}^{\prime} \mathrm{UTR}$ and $\mathrm{vC} / \mathrm{b}^{\prime} \mathrm{UTR}$ were passaged in PK-15 cells every 3 days and both chimeric viruses were passaged for a total of 31 passages. The viruses amplified in PK-15 cells (p3, 3rd passaged) were used as the parent viruses for comparison. Viral RNA copy numbers and virus titers were measured every 10 passages in PK-15 cells. For $\mathrm{vC} / \mathrm{SM}^{\prime} \mathrm{UTR}$, significantly increased RNA copy numbers were observed between p3 and p11, p11 and p21 at 24 h post-infection, and increased virus titers from p3 to p11 and p11 to p21 were observed (Figure $1 \mathrm{c}, \mathrm{d}$ ). However, for vC/b3'UTR, both significantly increased virus replication and infectious virus production were observed from $\mathrm{p} 11$ to p21 and p21 to p31, and significantly increased RNA copy numbers between p3 and p11 appeared at $24 \mathrm{~h}$ post-infection (Figure 1c,d). Moreover, the one-step growth curve of each 
virus exhibited a similar proliferation trend (Figure 1e). The serial passages also resulted in increased plaque sizes for both $\mathrm{vC} / \mathrm{SM} 3^{\prime} \mathrm{UTR}$ and $\mathrm{vC} / \mathrm{b} 3^{\prime} \mathrm{UTR}$ (Figure 1f).

To evaluate virus genetic stability, the whole genomes of 31st passaged $\mathrm{vC} / \mathrm{SM}^{\prime} \mathrm{UTR}$ and $\mathrm{vC} / \mathrm{b} 3^{\prime} \mathrm{UTR}$ were sequenced. The mutation sites observed in 31st passaged viruses were further sequenced in 11th and 21st passaged viruses for comparison (Table 2). Compared to parent viruses, the $5^{\prime} \mathrm{UTR}$ and $3^{\prime} \mathrm{UTR}$ sequences of 31st passaged vC/SM3 ${ }^{\prime} \mathrm{UTR}$ and $\mathrm{vC} / \mathrm{b} 3^{\prime} \mathrm{UTR}$ had no change. Five amino acid mutations were detected in the polyprotein of 31st passaged $\mathrm{vC} / \mathrm{SM}^{\prime} \mathrm{UTR}$ or $\mathrm{vC} / \mathrm{b3}^{\prime} \mathrm{UTR}$, respectively. The mutations S476R, M979K and P3342T occurred in both 31st passaged $\mathrm{vC} / \mathrm{SM}^{\prime} \mathrm{UTR}$ and $\mathrm{vC} / \mathrm{b} 3^{\prime} \mathrm{UTR}$. The mutations L2671M and G3431S were only observed in 31st passaged $\mathrm{vC} / \mathrm{SM}^{\prime} \mathrm{UTR}$. T745I and $\mathrm{N} 2494 \mathrm{H}$ occurred only in 31st passaged vC/b3'UTR. For vC/SM3'UTR, M979K mutation in 11th passaged virus resulted in the significantly increased viral RNA copy number and virus titer compared to 3rd parent virus. L2671M, P3342T, and M979K mutations in 21st passaged virus may have synergistically contributed to the change of virus characteristics. S476R and G3431S mutations in the 31st passaged virus failed to affect virus characteristics compared to the 21st passaged virus. For vC/b3'UTR, P3342T and the slight M979K mutations in the 21st passaged virus resulted in the significantly increased viral RNA copy number and virus titer compared to the 11th passaged virus. S476R, T745I, M979K, and $\mathrm{N} 2494 \mathrm{H}$ mutations in the 31st passaged virus may have synergistically contributed to the change of virus characteristics compared to the 21st passaged virus. We previously demonstrated that the mutation M979K in E2 increased infectious virus production, cell to cell spread and virulence for pig [38]. We reasonably speculated that the mutation P162T (P3342T in polyprotein) in NS5B plays a vital role in regulating virus replication.

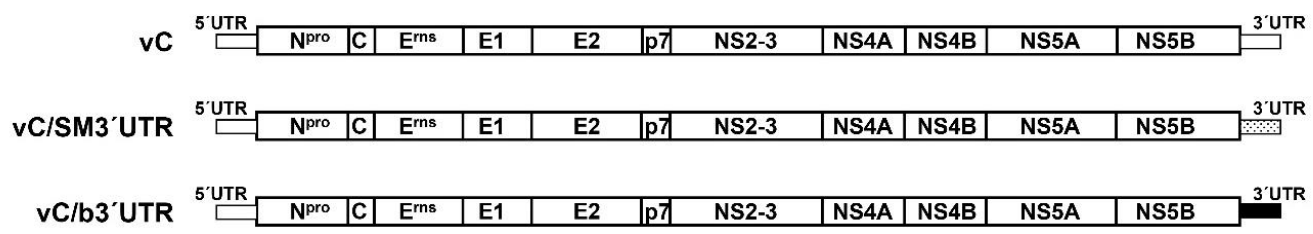

(a)


(b)
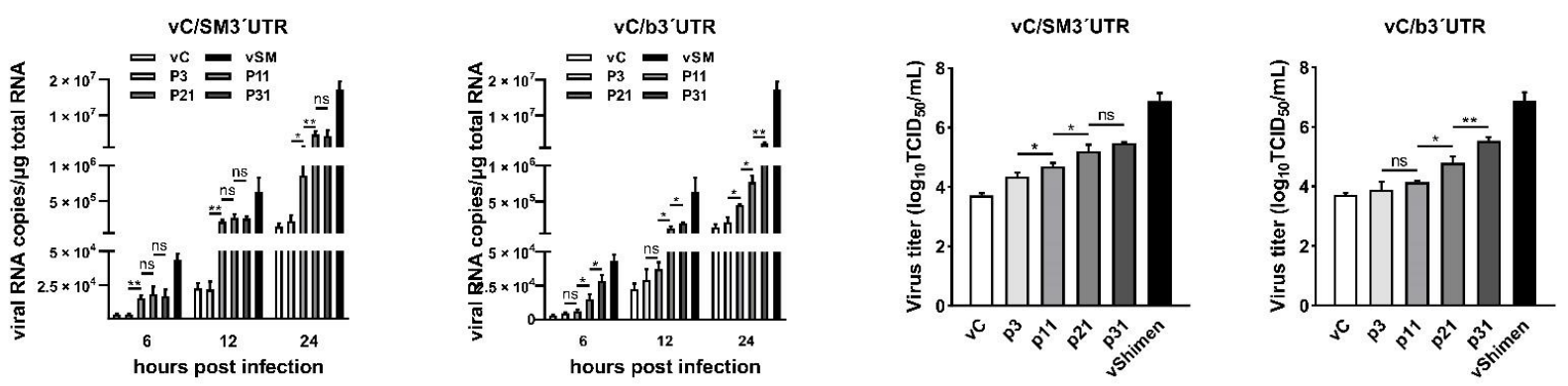

(c)

(d)

Figure 1. Cont. 

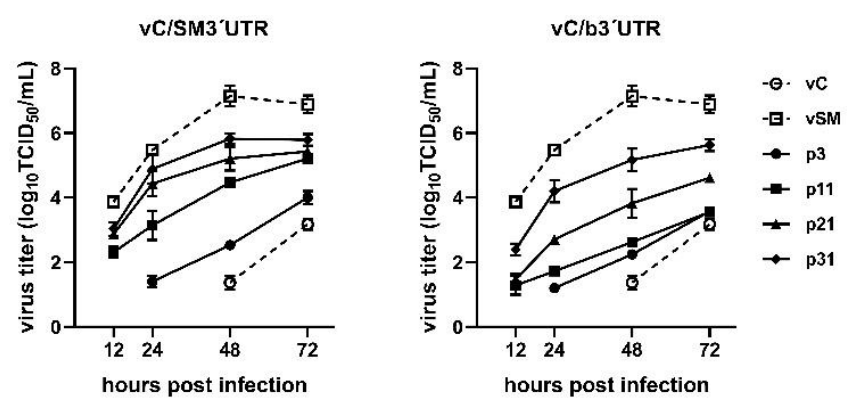

(e)

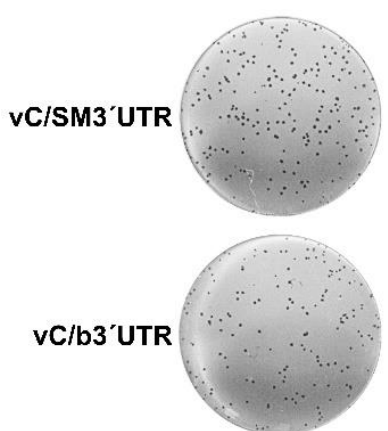

p3

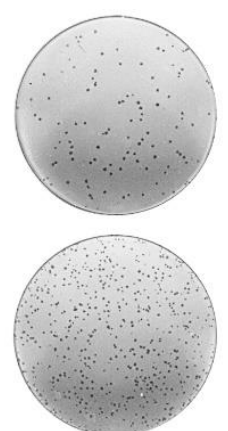

p11

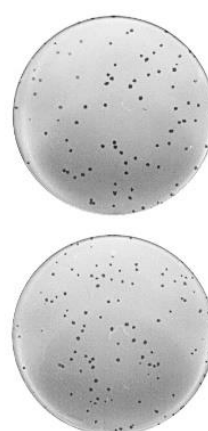

p21

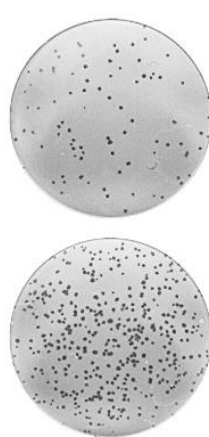

p31

(f)

Figure 1. Rescue of chimeric classical swine fever virus (CSFV) vaccine C strains containing pestivirus $3^{\prime} \mathrm{UTR}$ substitution and characteristics of passaged viruses. (a) Schematic representation of the cDNA clones of chimeric CSFV C strains containing $3^{\prime} \mathrm{UTR}$ substitution. (b) Rescue of infectious chimeric viruses vC/SM3'UTR and vC/b3'UTR. PK- 15 cells infected with the culture supernatant of transfected cells were analyzed by immunofluorescence (IF) staining with an NS3-specific antibody at $24 \mathrm{~h}$ post-infection. The microscopy images were captured at $100 \times$ magnification. (c) Genome replication efficiency of passaged viruses. PK-15 cells were infected with passaged chimeric viruses p3, p11, p21, and p31 at an MOI of 0.001 , respectively. The total RNA was extracted from the infected cells at the indicated times and viral RNA copy numbers were determined by qRT-PCR. The results were recorded from three independent experiments. ns, no significant; ${ }^{*}, p<0.05$; ${ }^{* *}, p<0.01$. (d) Virus titers of passaged viruses. PK-15 cells were infected with passaged viruses at an MOI of 0.01 . Virus titers were measured at $72 \mathrm{~h}$ post-infection by titration of the $\mathrm{TCID}_{50} / \mathrm{mL}$. Data are presented as the mean values \pm SD from three independent experiments. The comparisons of the values were performed using Student's $t$-test. ns, no significant; $*, p<0.05 ;{ }^{* *}, p<0.01$. (e) Growth kinetics of passaged viruses. PK-15 cells were infected with passaged viruses at an MOI of 0.001. Data are presented as the mean values \pm SD from three independent experiments. (f) Plaque morphology of passaged viruses. SK-6 cells infected with passaged viruses were analyzed by immunohistochemical staining with an NS3-specific antibody at $96 \mathrm{~h}$ post-infection. The images of plaque morphology were obtained at $1 \times$ magnification.

Table 2. Amino acid mutations in the continuous passages of two $3^{\prime}$ UTR substituted chimeric viruses.

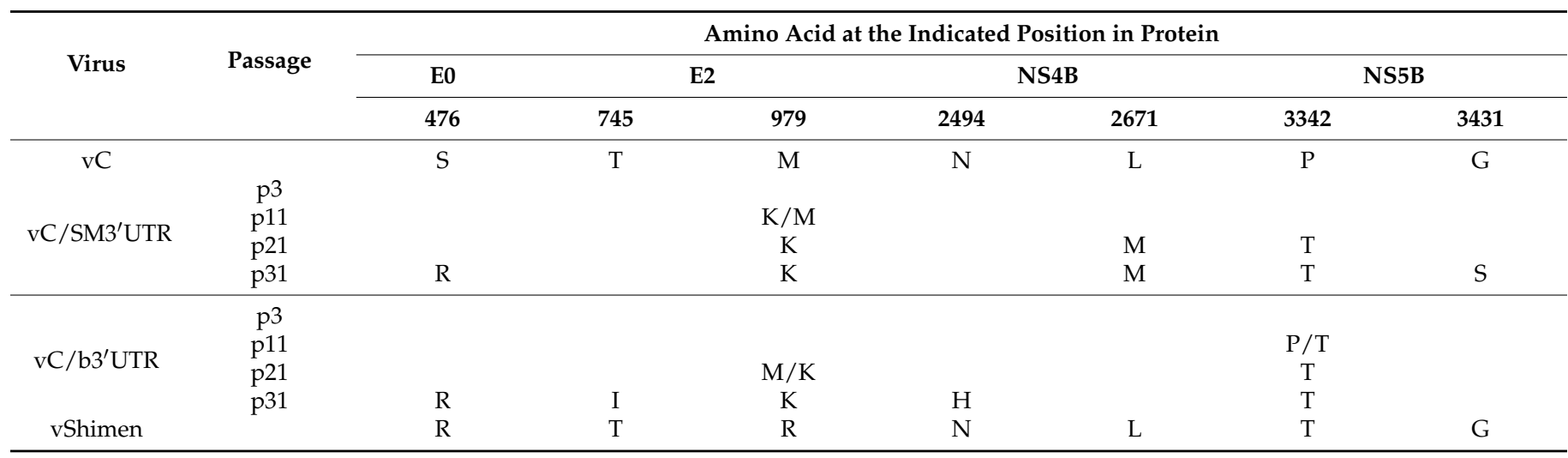




\subsection{Proline to Threonine Mutation at Position 162 of NS5B Increased Chimeric CSFVs RNA Replication and Infectious Virus Production}

To investigate the effect of NS5B P162T mutation on virus characteristics, the singlesite mutant was constructed based on the infectious $\mathrm{CDNA}$ clone $\mathrm{pSPT}_{\mathrm{I}} / \mathrm{C} / \mathrm{SM}^{\prime} \mathrm{UTR}$ or $\mathrm{pSPT}_{\mathrm{I}} / \mathrm{C} / \mathrm{b3}^{\prime} \mathrm{UTR}$, respectively (Figure $\left.2 \mathrm{a}\right)$. The mutant viruses (vC/SM3 ${ }^{\prime} \mathrm{UTR}_{\mathrm{P} 162 \mathrm{~T}}$ and $\mathrm{vC} / \mathrm{b3}^{\prime} \mathrm{UTR}_{\mathrm{P} 162 \mathrm{~T}}$ ) were rescued. Viral RNA copy numbers and virus titers were determined in PK-15 cells at an MOI of 0.01. Data showed that the mutants $\mathrm{vC} / \mathrm{SM}^{\prime} \mathrm{UTR}_{\mathrm{P} 162 \mathrm{~T}}$ and $\mathrm{vC} / \mathrm{b3}^{\prime} \mathrm{UTR}_{\mathrm{P} 162 \mathrm{~T}}$ displayed significantly increased viral RNA copy numbers and virus titers compared to parent vC/SM3'UTR and vC/b3'UTR, respectively (Figure $2 b, c$ ).

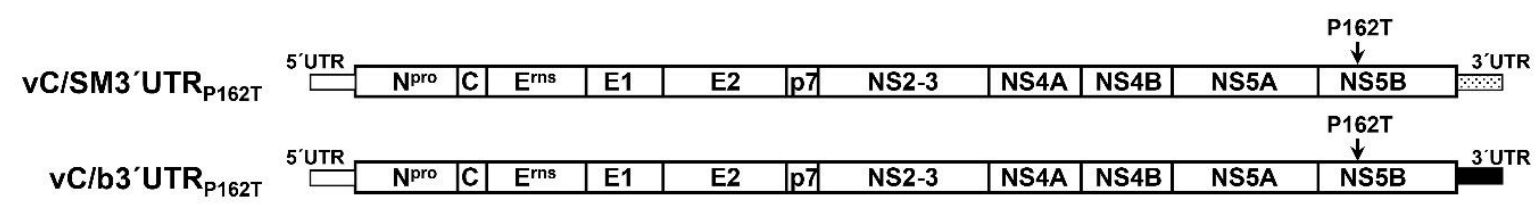

(a)

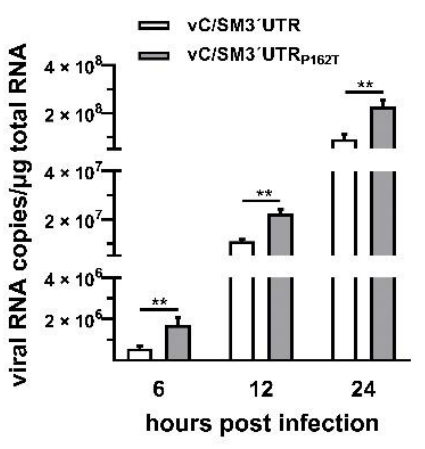

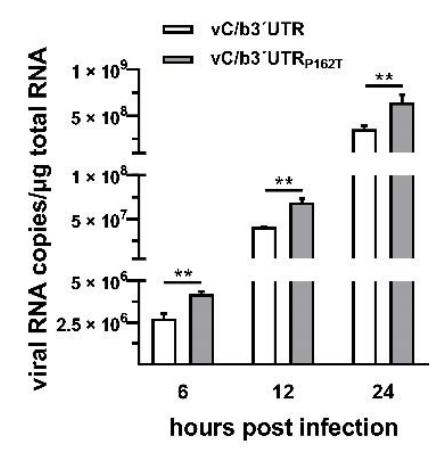

(b)
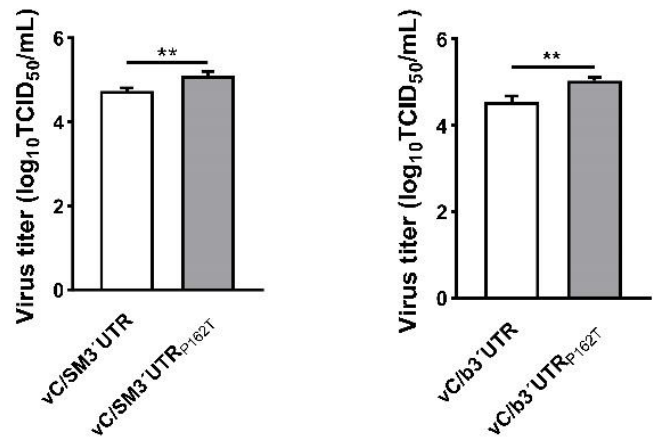

(c)

Figure 2. Viral genome replication and virus titers of chimeric CSFV C strains containing NS5B P162T mutation. (a) Schematic representation of the cDNA clones of $\mathrm{vC} / \mathrm{SM}^{\prime} \mathrm{UTR}_{\mathrm{P} 162 \mathrm{~T}}$ and $\mathrm{vC} / \mathrm{b3}^{\prime} \mathrm{UTR}_{\mathrm{P} 162 \mathrm{~T}}$. (b) Genome replication efficiency of vC/SM3 ${ }^{\prime} \mathrm{UTR}_{\mathrm{P} 162 \mathrm{~T}}$ and $\mathrm{vC} / \mathrm{b}^{\prime} \mathrm{UTR}_{\mathrm{P} 162 \mathrm{~T}}$ mutants. PK-15 cells were infected with chimeric viruses and their P162T mutants at an MOI of 0.01. The total RNA was extracted from the infected cells at the indicated time and viral RNA copy numbers were determined by qRT-PCR. Data were recorded from three independent experiments. (c) Virus titers of $\mathrm{vC} / \mathrm{SM}^{\prime} \mathrm{UTR}_{\mathrm{P} 162 \mathrm{~T}}$ and $\mathrm{vC} / \mathrm{b3}^{\prime} \mathrm{UTR}_{\mathrm{P} 162 \mathrm{~T}}$ mutants. PK-15 cells were infected with the viruses at an MOI of 0.01 and the culture supernatants collected at $72 \mathrm{~h}$ post-infection were used for virus titration. Virus titers were expressed as the $\mathrm{TCID}_{50} / \mathrm{mL}$. Data are represented as the mean values $\pm \mathrm{SD}$ from three independent experiments. ${ }^{* *}, p<0.01$.

\subsection{The Influence of P162T Mutation on Fever Response and Virus Replication in Rabbits}

Rabbit is a useful animal model for evaluating replication efficiency of CSFV C strain in vivo $[9,43,51]$. To investigate the effect of NS5B P162T mutation on virus in vivo, three groups of eight rabbits were inoculated with $\mathrm{vC} / \mathrm{SM}^{\prime} \mathrm{UTR}, \mathrm{vC} / \mathrm{SM}^{\prime} \mathrm{UTR}_{\mathrm{P} 162 \mathrm{~T}}$ or Dulbecco's modified Eagle's medium (DMEM), respectively. The group inoculated with DMEM was used as a negative control. Rectal temperature was recorded every $6 \mathrm{~h}$ after inoculation until $72 \mathrm{~h}$ post-inoculation. In contrast to DMEM, vC/SM3'UTR, vC/SM3 ${ }^{\prime} \mathrm{UTR}_{\mathrm{P} 162 \mathrm{~T}}$ induced different degrees of fever responses in rabbits. The maximum average temperature of $\mathrm{vC} / \mathrm{SM}^{\prime} \mathrm{UTR}_{\mathrm{P} 162 \mathrm{~T}}$ was $0.7^{\circ} \mathrm{C}$ lower than that of $\mathrm{vC} / \mathrm{SM}^{\prime} \mathrm{UTR}$ (Table 3). All rabbits were euthanized for determining viral RNA copy numbers in the spleens by qRTPCR. The significantly increased viral RNA copies in the spleens of rabbits infected with $\mathrm{vC} / \mathrm{SM}^{\prime} \mathrm{UTR}_{\mathrm{P} 162 \mathrm{~T}}$ were observed compared to that with vC/SM3'UTR (Table 3). 
Table 3. Fever response and viral replication in the spleens of the rabbits inoculated with viruses.

\begin{tabular}{|c|c|c|c|c|c|c|c|}
\hline \multirow{2}{*}{ Inoculum } & \multirow{2}{*}{$\begin{array}{c}\text { Dose } \\
\left(\operatorname{TCID}_{50}\right)\end{array}$} & \multicolumn{4}{|c|}{ Fever Response } & \multicolumn{2}{|c|}{ Viral Replication } \\
\hline & & $\begin{array}{l}\text { No. with } \\
\text { Fever/Total }\end{array}$ & $\begin{array}{l}\text { No. of } \\
\text { Hours to } \\
\text { Onset }\end{array}$ & $\begin{array}{l}\text { Duration } \\
\text { (Hours) }\end{array}$ & $\begin{array}{c}\text { Maximum } \\
\text { Average } \\
\text { Temperature }\left({ }^{\circ} \mathrm{C}\right)\end{array}$ & $\begin{array}{l}\text { No. with Viral } \\
\text { Replication/Total }\end{array}$ & 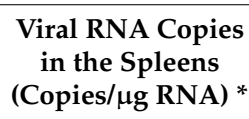 \\
\hline vC/SM3'UTR & $10^{4}$ & $3 / 3$ & 30 & 10 & 41.0 & $3 / 3$ & $(1.76 \pm 0.42) \times 10^{4}$ \\
\hline $\mathrm{vC} / \mathrm{SM}^{\prime} \mathrm{UTR}_{\mathrm{P} 162 \mathrm{~T}}$ & $10^{4}$ & $3 / 3$ & 30 & 8 & 40.3 & $3 / 3$ & $(3.48 \pm 0.97) \times 10^{4}$ \\
\hline $\begin{array}{l}\text { Negative } \\
\text { control }\end{array}$ & / & $0 / 2$ & / & / & / & $0 / 2$ & 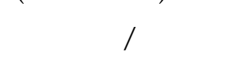 \\
\hline
\end{tabular}

${ }^{*}$ Data are presented as mean \pm SD of 3 individual rabbits. Statistical analysis was performed using Student's $t$-test. $p<0.05$.

\subsection{NS5B P162T Mutation Increased RNA-Dependent RNA Polymerase Activity In Vitro}

NS5B, an RNA-dependent RNA polymerase, is responsible for pestivirus genome replication. To investigate the influence of NS5B P162T mutation on RdRp activity, we expressed an NS5B construct comprising residues 1-694 with deletion of the C-terminal 24aa hydrophobic region as the wild-type $\left(\mathrm{NS} \mathrm{B}_{\mathrm{WT}}\right)$. P162T mutation was introduced into $\mathrm{NS}_{5} \mathrm{~B}_{W T}$ to generate a mutant NS5B $\mathrm{B}_{\mathrm{P} 162 \mathrm{~T}}$. Both NS5B $\mathrm{B}_{\mathrm{WT}}$ and NS5B $\mathrm{B}_{\mathrm{P} 162 \mathrm{~T}}$ were expressed and purified. After being judged by SDS-PAGE (Figure S1), purified proteins were used for subsequent RdRp assays in vitro.

To measure de novo RdRp activity, a GG dinucleotide (P2) driven RdRp assay was performed as previously described [30,48,52]. We compared the RdRp activity of NS5B $B_{W T}$ and NS5B $\mathrm{B}_{\mathrm{P} 162 \mathrm{~T}}$ using the assay with a 30-nt RNA template (T30). T30 and P2 were annealed to form T30/P2 RNA substrate, and a 9-nt product (P9) was generated when ATP and UTP were provided as the only two NTP substrates (Figure 3a). The P9 product was detected at different time points by denaturing urea polyacrylamide gel electrophoresis (PAGE) (Figure $3 b$ ) and the apparent P9 conversion rate constant $\left(k_{\text {conv }}\right)$ was calculated by the intensity of P9 as a function of time (Figure 3c). Data showed that the $k_{\text {conv }}$ value of $\mathrm{NS5B}_{\mathrm{P} 162 \mathrm{~T}}$ was more than twice that of $\mathrm{NS} \mathrm{B}_{\mathrm{WT}}\left(0.03072 \mathrm{~min}^{-1} \mathrm{vs} .0 .01433 \mathrm{~min}^{-1}\right)$, indicating that the P162T mutation in NS5B upregulated de novo RdRp activity.

We next measured the RdRp activity using different RNA templates with a simple colorimetric assay $[49,50]$. To detect the polymerization reaction rate, the reaction product pyrophosphate (PPi) was measured using a phosphate-based colorimetric method by hydrolyzing PPi to two inorganic phosphates $(\mathrm{Pi})$. The accumulation of Pi was detected at different time points to yield an apparent synthetic rate constant $\left(k_{s y n t}\right)$ of RNA synthesis. For the poly $(\mathrm{C})$ template, the values of $k_{\text {synt }}$ were $0.02637 \mathrm{~min}^{-1}$ and $0.05529 \mathrm{~min}^{-1}$ characterized by NS5B $\mathrm{B}_{\mathrm{WT}}$ and NS5B $\mathrm{B}_{\mathrm{P} 162 \mathrm{~T}}$, respectively (Figure 3d). For viral template, (+) CSFV $/ 3^{\prime}$ UTR, the values of $k_{\text {synt }}$ of NS5B BWT and NS5B P162T were $0.02189 \mathrm{~min}^{-1}$ and $0.02980 \mathrm{~min}^{-1}$, respectively (Figure 3e). These data indicated that the P162T mutation increased NS5B RdRp activity for different RNA templates in vitro. 


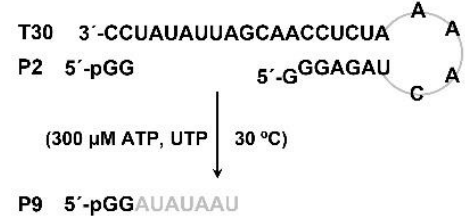

(a)

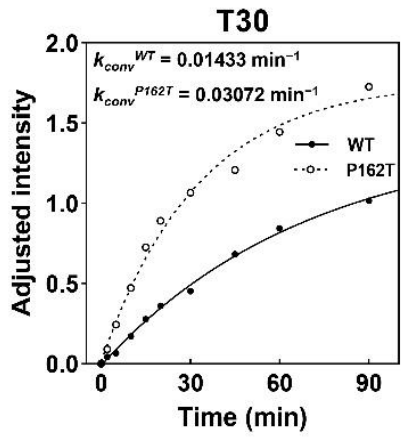

(c)
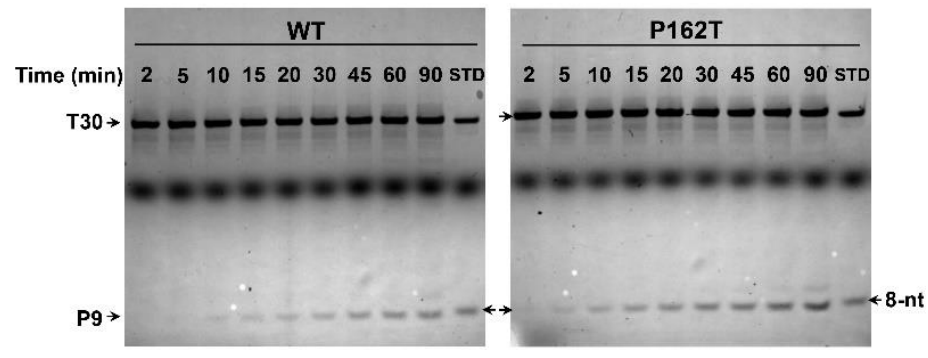

(b)

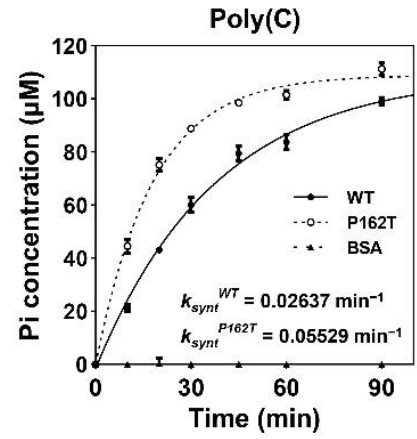

(d)

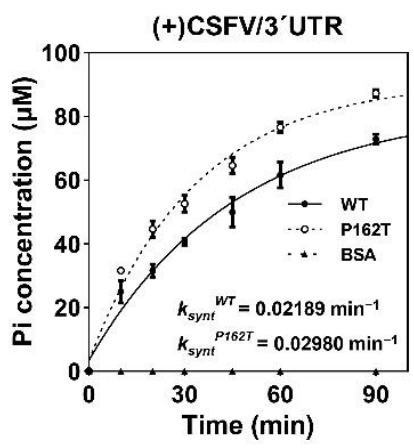

(e)

Figure 3. The NS5B RdRp activity in vitro. (a) Schematic diagram of the de novo RdRp assay in vitro. T30/P2 was used as the RNA substrate. The template strand T30 directed a 7-nt (grey) extension of the dinucleotide primer P2 (black) to produce a 9-nt product (P9) when ATP and UTP were supplied as the only NTP substrates. (b) Denaturing urea-PAGE analysis of the de novo RdRp assay. The P9 accumulation was monitored at the indicated time points for NS5B $\mathrm{B}_{\mathrm{WT}}$ and NS5B $_{\text {P162T }}$ constructs. The oval-shaped band between T30 and P9 is the Xylene Cyanol FF. An 8-nt marker was used as the standard sample for quantitation (set to 1). The 8-nt marker bearing hydroxyl groups at the $5^{\prime}$-end was chemically synthesized and therefore migrated slower than the P9 bearing a $5^{\prime}$-phosphate. STD, standard sample containing T30 and 8-nt marker. (c) Comparison of de novo RdRp activity for $\mathrm{NS5B}_{\mathrm{WT}}$ and $\mathrm{NS5B}_{\mathrm{P} 162 \mathrm{~T}}$. The relative intensity of P9 product was plotted as a function of time to estimate the apparent P9 conversion rate constant $\left(k_{\text {conv }}\right)$ by fitting to a one phase exponential

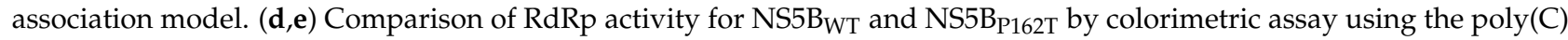
and (+) CSFV / $3^{\prime}$ UTR templates. The Pi concentration was plotted as a function of time to fit to a one phase exponential association model and the apparent synthetic rate constant $\left(k_{\text {synt }}\right)$ was estimated.

\subsection{The RdRp Elongation Activity and Stability of Elongation Complex (EC) Were Not Affected by NS5B P162T Mutation}

RNA synthesis catalyzed by NS5B RdRp can be divided into three phases: apo state, initiation, and elongation [27]. To accurately understand the catalytic mechanism of NS5B $\mathrm{B}_{\mathrm{P} 162 \mathrm{~T}}$, we first tested the RdRp elongation activity and stability of $\mathrm{NS} \mathrm{B}_{\mathrm{P} 162 \mathrm{~T}}$ elongation complex (EC). A P9 to P10 single nucleotide elongation assay was used to analyze the elongation activity of EC. The EC containing the 9-nt product (EC9) in de novo RdRp assay was employed to assess elongation activity by using a high-salt or heparin challenge strategy, which has been widely used in nucleic acids polymerase studies $[30,52,53]$. The single nucleotide elongation assay was designed in a two-step format. ATP and UTP were supplied to generate the EC9 in the first step. The proportions of $\mathrm{P} 10$ misincorporation product $\left(\mathrm{P} 10_{\mathrm{m}}\right)$ in all assays were similar (Figure $4 \mathrm{~b}-\mathrm{d}$, lanes with S1). In the second step, high-salt $(200 \mathrm{mM} \mathrm{NaCl})$ was introduced to block initiation events after removal of the originally supplied ATP and UTP, and then CTP was added as the only substrate to probe EC9-drived formation of EC10 (Figure 4a). We compared the

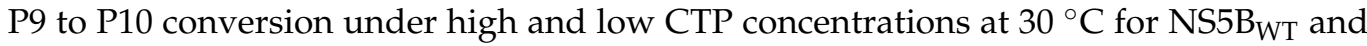


NS5B $\mathrm{B}_{162 \mathrm{~T}}$. At $300 \mu \mathrm{M}$ CTP concentration, the conversion rates of $\mathrm{P} 9$ to $\mathrm{P} 10$ catalyzed by $\mathrm{NS5B}_{\mathrm{WT}}$ and $\mathrm{NS} \mathrm{B}_{\mathrm{P} 162 \mathrm{~T}}$ were $80.3 \%$ and $80.4 \%$ at " $0 \mathrm{~min}^{\prime \prime}$, and $89.1 \%$ and $94.1 \%$ at $1 \mathrm{~min}$, respectively (Figure $4 \mathrm{~b}$ ). At $5 \mu \mathrm{M}$ CTP concentration, decreased conversion rates of P9 to P10 were observed and the conversion rates catalyzed by NS5B $\mathrm{B}_{\mathrm{WT}}$ and NS55 $\mathrm{B}_{\mathrm{P} 162 \mathrm{~T}}$ were $32.1 \%, 32.6 \%$ at " $0 \mathrm{~min}$ " and $92.4 \%, 93.8 \%$ at $1 \mathrm{~min}$, respectively (Figure $4 \mathrm{c}$ ). We determined

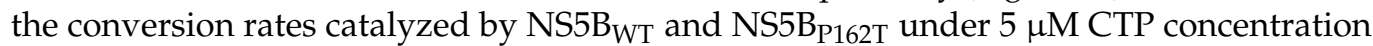
at $0{ }^{\circ} \mathrm{C}$. The conversion rates of NS5B $\mathrm{BT}_{\mathrm{WT}}$ and NS5B $\mathrm{B}_{\mathrm{P} 162 \mathrm{~T}}$ at detailed time points ("0s", "20s", "40s", "60s") were almost identical (Figure 4d). Data suggested that the elongation activity of NS5B EC was not affected by the P162T mutation.

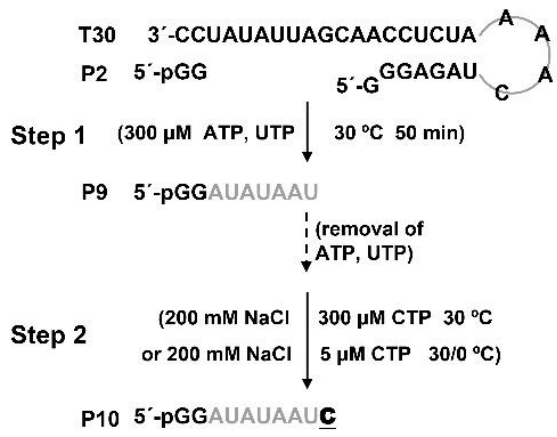

(a)

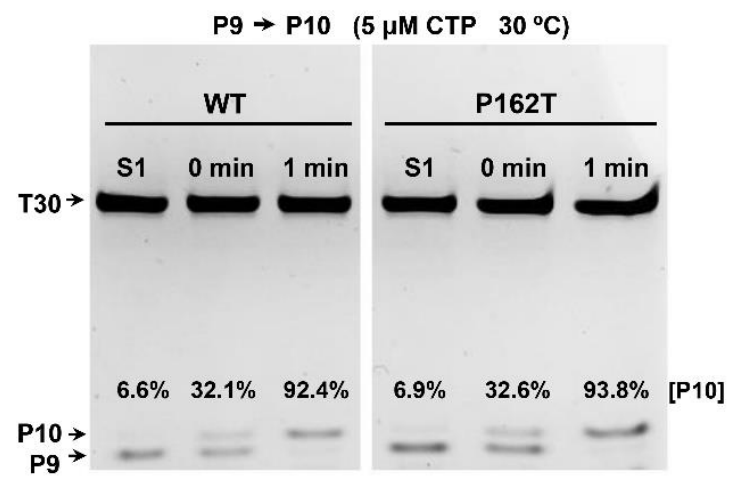

(c)

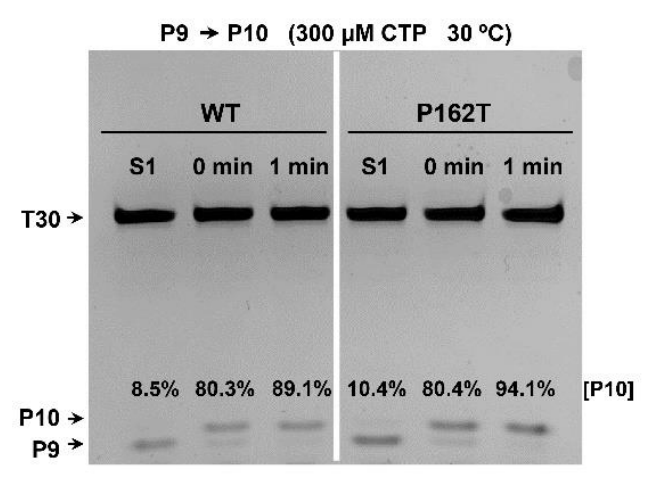

(b)

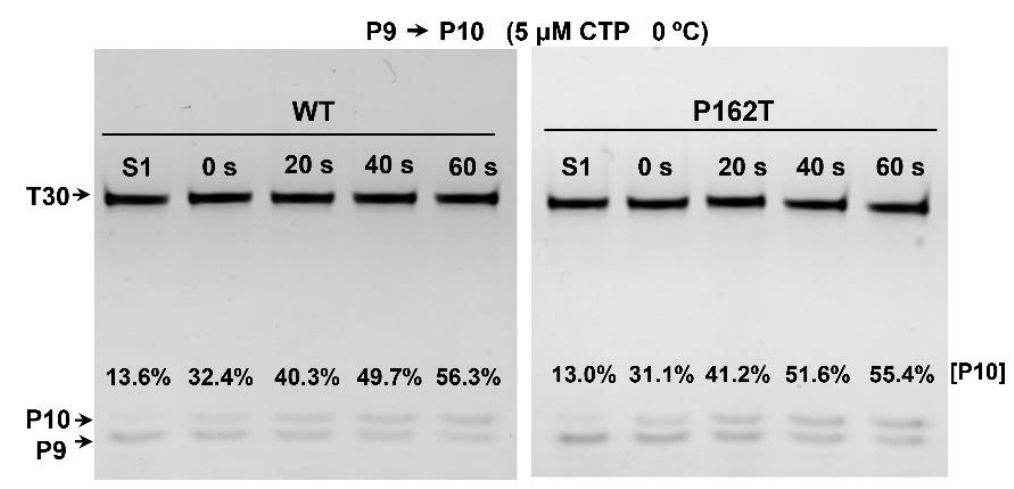

(d)

Figure 4. The elongation activity of RdRp elongation complex. (a) Schematic diagram of the P9 to P10 single nucleotide elongation assay. The first step of the assay was identical to the de novo RdRp assay. In the second step, CTP was supplied as the only NTP substrate and the $\mathrm{NaCl}$ concentration was raised to $200 \mathrm{mM}$ after the removal of ATP and UTP.

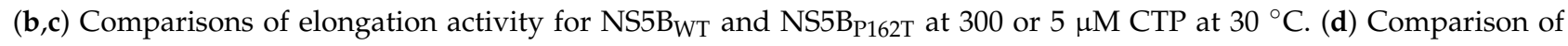
elongation activity for $\mathrm{NS} \mathrm{B}_{\mathrm{WT}}$ and $\mathrm{NS} \mathrm{B}_{\mathrm{P} 162 \mathrm{~T}}$ at $5 \mu \mathrm{MCTP}$ at $0{ }^{\circ} \mathrm{C}$. The fraction of $\mathrm{P} 10$ intensity is shown in each lane. S1, sample from step 1.

To further investigate the stability of EC, a high-salt $(500 \mathrm{mM} \mathrm{NaCl})$ incubation challenge was added into the single nucleotide elongation assay (Figure 5a). The proportion of EC9 which survived the high-salt challenge reflected the stability of EC. Conversion rate of P9 to P10 was the proportion of EC9 survival because only the surviving EC9 had the capacity to generate EC10. By measuring the conversion rates from P9 to P10 catalyzed by $\mathrm{NS5B}_{\mathrm{WT}}$ and $\mathrm{NS5B}_{\mathrm{P} 162 \mathrm{~T}}$, we found that the EC9 comprised of NS5B $\mathrm{B}_{\mathrm{WT}}$ or $\mathrm{NS}_{\mathrm{B}} \mathrm{B}_{\mathrm{P} 162 \mathrm{~T}}$ exhibited similar inactivation rate constants $\left(0.04364 \mathrm{~h}^{-1}\right.$ and $\left.0.04185 \mathrm{~h}^{-1}\right)$ and comparable half-life period (15.88 $\mathrm{h}$ and $16.56 \mathrm{~h}$ ) (Figure 5c). Therefore, the P162T mutation had no effect on the stability of the RdRp elongation complex. 


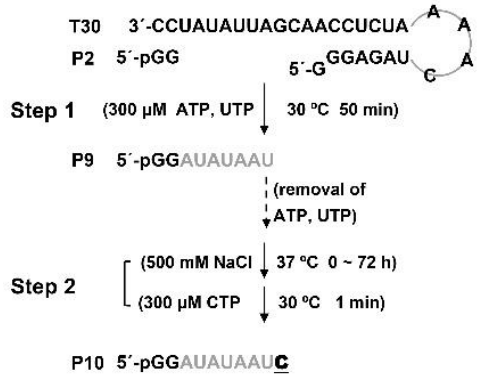

(a)

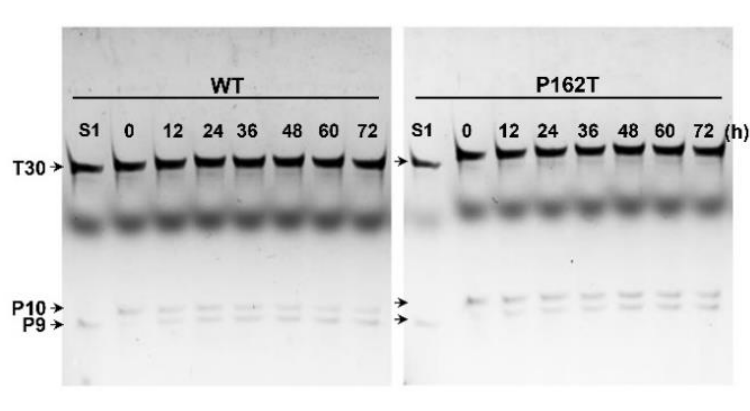

(b)

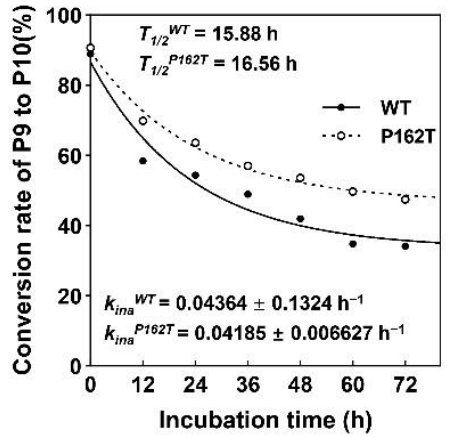

(c)

Figure 5. The stability of the RdRp elongation complex. (a) Schematic diagram of the stability assay. The first step of the assay was identical to the de novo RdRp assay. In the second step, a high-salt ( $500 \mathrm{mM} \mathrm{NaCl}$ ) challenge was added before the supply of CTP. (b) Denaturing urea-PAGE analysis of the P9 to P10 conversion. The oval-shaped band between T30

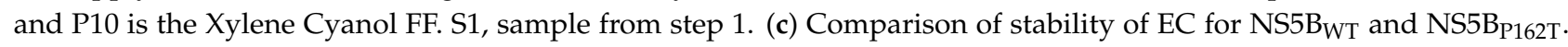
The conversion rate of P9 to P10 was plotted as a function of incubation time to estimate the apparent EC inactivation rate constant $\left(k_{\text {ina }}\right)$ and half-life period $\left(T_{1 / 2}\right)$ by fitting to a one phase exponential decay model.

\subsection{The Increased RdRp Activity of NS5B $B_{P 162 T}$ Mutant Resulted from Enhanced Initiation Efficiency of RNA Synthesis}

To investigate the RdRp activity during initiation stage, the relative catalytic rates

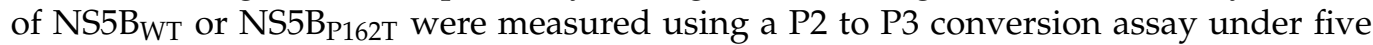
different ATP concentrations (Figure 6a,b). Experimental data were used to fit a MichaelisMenten equation (Figure 6c). The P3 band intensities were controlled to be within the linear range of Stains-All based staining method by optimizing the reaction time [48]. The Michaelis constant $\left(K_{M}\right)$ values of $\mathrm{NS} \mathrm{B}_{\mathrm{WT}}$ and $\mathrm{NS5B}_{\mathrm{P} 162 \mathrm{~T}}$ were almost consistent $(681.8 \mu \mathrm{M}$ vs. $653.6 \mu \mathrm{M})$, while the relative maximum conversion rate constant $\left(V_{\max }\right)$ value

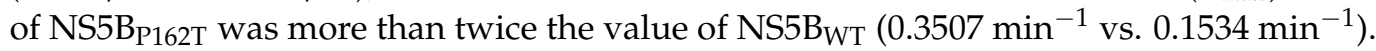

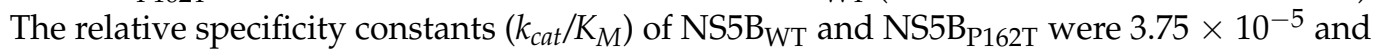
$8.94 \times 10^{-5}$ (Figure 6c). Data indicated that NS5B P162T mutation increased the RdRp initiation efficiency. 


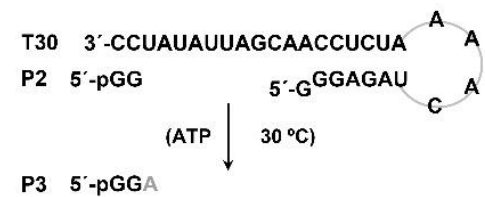

(a)

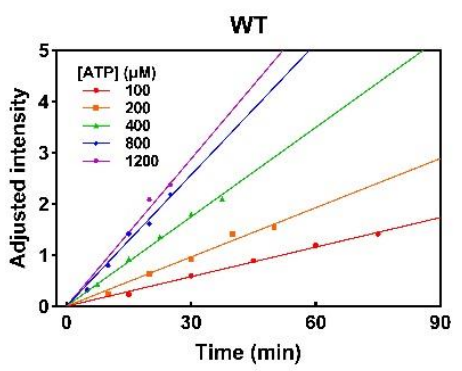

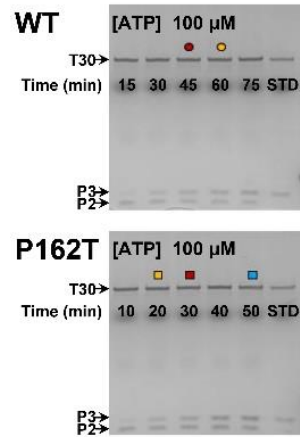
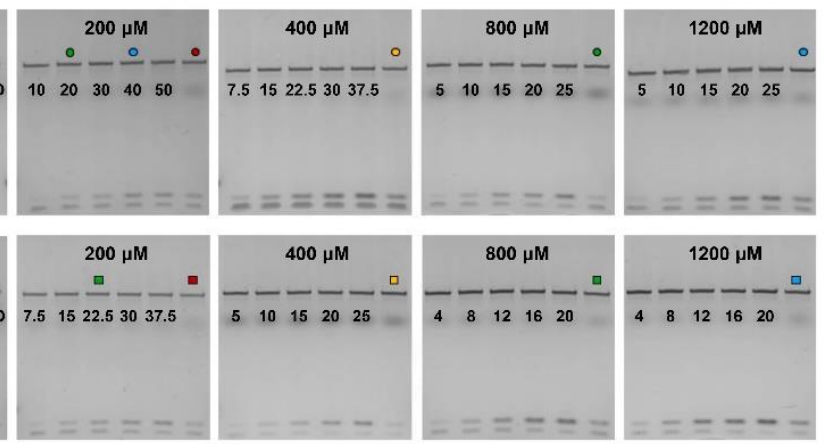

(b)

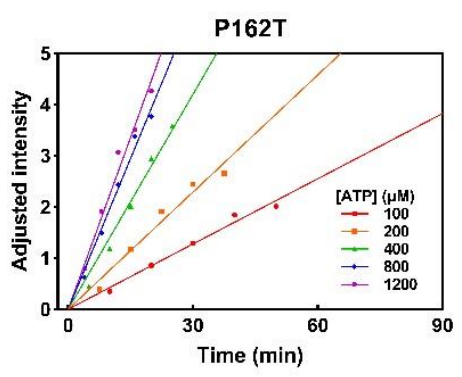

(c)

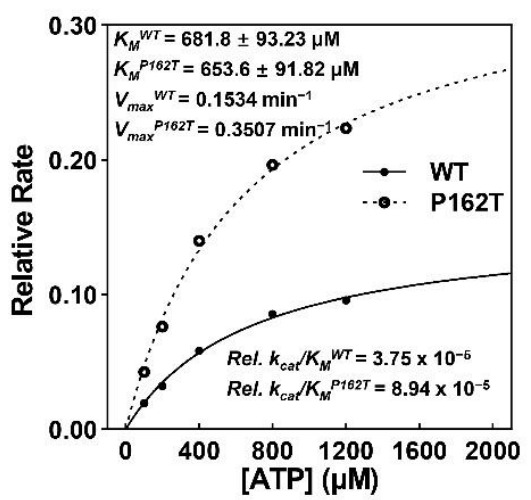

Figure 6. Characteristics of the initiation kinetics on NS5B $\mathrm{BWT}_{\mathrm{WT}}$ and NS5B $\mathrm{B}_{\mathrm{P} 162 \mathrm{~T}}$. (a) Schematic diagram of the P2 to P3 conversion assay. (b) Denaturing urea-PAGE analysis of the P3 formation under different ATP concentrations by NS5B $\mathrm{B}_{\mathrm{WT}}$ and $\mathrm{NS}_{5} \mathrm{~B}_{\mathrm{P} 162 \mathrm{~T}}$ constructs. The lanes marked with same color-coded icons represented the banks from the same sample which was used to correlate band intensity in different gels. STD, standard sample containing P3 from the pre-experiment. (c) Comparison of the initiation efficiency for $\mathrm{NS} \mathrm{B}_{\mathrm{WT}}$ and $\mathrm{NS}_{\mathrm{S}} \mathrm{B}_{\mathrm{P} 162 \mathrm{~T}}$. The relative reaction rates of $\mathrm{NS}_{5} \mathrm{~B}_{\mathrm{WT}}$ and $\mathrm{NS}_{\mathrm{B}} \mathrm{B}_{\mathrm{P} 162 \mathrm{~T}}$ constructs were estimated by the equation about the adjusted intensity of the P3 as a function of time at five ATP concentrations. The rate values were then fit to the Michaelis-Menten equation to generate the Michaelis constant $\left(K_{M}\right)$, relative maximum reaction rate $\left(V_{\max }\right)$, and relative specificity constant $\left(k_{c a t} / K_{M}\right)$.

\section{Discussion}

CSFV and BVDV belong to the genus Pestivirus. Clinically, pigs can be simultaneously infected with CSFV, BVDV-1, and BVDV-2 [54]. Some genome elements and viral proteins of CSFV can be substituted with their counterparts in genus Pestivirus [55-57]. The 3'UTRs from CSFV C strain and BVDV NADL strain have similar predicted secondary structures [58,59], and the $3^{\prime}$ UTR substitution has not effect on replication across species in chimeric C strains [9]. In this study, the chimeric CSFV C strain containing BVDV NADL $3^{\prime}$ UTR substitution was successfully rescued. Therefore, the $3^{\prime}$ UTR substitution of CSFV with BVDV NADL $3^{\prime}$ UTR is feasible.

In our study, five amino acid mutations were identified in 31st passages of both passaged vC/SM3 ${ }^{\prime} \mathrm{UTR}$ and $\mathrm{vC} / \mathrm{b}^{\prime}{ }^{\prime} \mathrm{UTR}$. For $\mathrm{vC} / \mathrm{SM}^{\prime} \mathrm{UTR}, \mathrm{S} 476 \mathrm{R}$ and G3431S mutations in 31st passaged virus had no influence on the viral genome replication and infectious virus production compared to 21st passaged virus. However, the single Ser-to-Arg mutation at position 476 in the CSFV $E^{\text {rns }}$ resulted in the virus binding to cells from a heparan sulfate (HS)-independent mode to an HS-dependent mode [60,61]. For vC/b3'UTR, S476R, T745I, and $\mathrm{N} 2494 \mathrm{H}$ in 31st passaged $\mathrm{vC} / \mathrm{b3}^{\prime} \mathrm{UTR}$ resulted in significantly increased viral genome 
replication and infectious virus production, and the T745I mutation probably played a vital role. T745I has been identified to enhance the infectious virus production, cell to cell spread, and pathogenicity [38]. Compared with other mutations, the M979K and P3342T occurred earlier in both passaged vC/SM3'UTR and vC/b3'UTR. Effect of P3342T mutation in CSFV BS5B is further addressed.

Alignment of amino acid sequences revealed that proline at position 3342 of CSFV polyprotein only existed in lapinized attenuated strains including vaccine C, Riems, LPC, and HCLV-India strains. In contrast, other CSFV strains, such as highly virulent and moderately virulent strains and another attenuated strains, the residue 3342 of polyprotein is threonine (data not shown). A previous study showed that the proline at position 3342 of CSFV C strain remained unchanged even in the 80th generation viruses [40]. In our study, the P3342T mutation was associated with the $3^{\prime} \mathrm{UTR}$ substitution and $\mathrm{vC} / \mathrm{SM} 3^{\prime} \mathrm{UTR}$ caused more severe fever response than $\mathrm{vC} / \mathrm{SM}^{\prime} \mathrm{UTR}_{\mathrm{P} 162 \mathrm{~T}}$ in rabbits, suggesting that the proline at position 3342 seems to originate from adaptive evolution of CSFV in rabbits. This discovery provided new insight to reveal the mechanism of CSFV proliferation across interspecific barriers in non-susceptible animals. On the other hand, the P3342T mutation increased the infectious virus production in vitro and even in vivo, and had potential practical value in upstream CSVF viral vaccine manufacturability.

In our study, the $\mathrm{vC} / \mathrm{SM}^{\prime} \mathrm{UTR}$ induced a severe rabbit fever response with a maximum average temperature of $41{ }^{\circ} \mathrm{C}$ (Table 3). Previous reports demonstrated that the chimeric CSFV C strain harboring Shimen $3^{\prime}$ UTR substitution failed to induce the fever response in the rabbits [9], and that the amino acid mutations in viruses or the substitutions of structure proteins could influence the fever response induced by $C$ strain in the rabbits [40,62-64]. Nine different amino acids in structure and non-structure proteins existed between our CSFV C strain and the C-strain/HVRI (GenBank: AY805221.1) by aligning the amino acid sequences of polyproteins (Table S1), suggesting that the fever response in the rabbits induced by CSFV C strains was probably regulated by both viral genome structure and amino acid composition.

The mutant $\mathrm{NS5B}_{\mathrm{P} 162 \mathrm{~T}}$ exhibited increased RdRp activity compared to NS5B $\mathrm{WT}$ using three types of RNA templates: T30, poly(C), and (+) CSFV/3'UTR [18,30,65]. We further demonstrated that the similar elongation activity and stability of EC were observed from NS5B $\mathrm{BT}_{\mathrm{WT}}$ and $\mathrm{NS5B}_{\mathrm{P} 162 \mathrm{~T}}$. However, mutant $\mathrm{NS5B}_{\mathrm{P} 162 \mathrm{~T}}$ displayed enhanced initiation efficiency of RNA synthesis independent of initial NTP binding because of the similar Michaelis constant $K_{M}$ [30]. The residue 162 is located at the N-terminal of an $\alpha$-helix in the index finger domain of CSFV NS5B structure close to the fingertip region [31,34]. The fingertip connects the finger domain with the thumb domain and results in the molecule having a unique globular shape with the active site cavity completely encircled $[30,31,66]$. The flexibility of the fingertip region seems to be an intrinsic property of the polymerase, which is important for the polymerase activity $[34,67,68]$. The fingertip region has been proposed to be involved in RNA template and NTP binding [31,34,69,70]. Mutation of residue 141 in the fingertip region of HCV NS5B corresponding to residue 163 in BVDV NS5B and CSFV NS5B resulted in drastically reduced polymerase activity [31,34,71]. HCV and BVDV replications were inhibited by the inhibitors which prevent the fingertips from moving [34,68]. The effect of P162T mutation in CSFV NS5B on initiation efficiency of RNA synthesis could be involved in the conformation change of the fingertip region. Previous studies identified that serial passages of chimera CSFV/CE23'UTR containing C strain $3^{\prime}$ UTR substitution resulted in alanine to threonine mutation of the residue 392 located in the tip of the middle finger near the residue 162 [31,72]. The relative positions of residue 162 and residue 392 are fixed both in CSFV and BVDV NS5B structures (Figure S2) [30,31,34,35]. The functional regulation between residue 162 in the index finger and residue 392 in the middle fingertip of NS5B may be meaningful and deserves attention.

In summary, we identified the mutation P162T in CSFV NS5B and addressed the effects of this point mutation on NS5B RdRp activity and virus replication. The P162T mutation occurred in the continuous passages of two chimeric viruses with $3^{\prime} \mathrm{UTR}$ substitution and 
influenced viral genomic RNA synthesis by changing initiation efficiency in vitro or in vivo. These findings help us understand the impact of $3^{\prime}$ UTR on virus adaptive evolution and brings insights into the intramolecular regulation mechanism of index finger domain of NS5B structure on RdRp activity.

Supplementary Materials: The following are available online at https:/ /www.mdpi.com/article/10 $.3390 / v 13081523 / \mathrm{s} 1$, Figure S1. SDS-PAGE gel of the purified NS5BWT and NS5BP162T. Wild-type and mutant NS5B proteins were purified to near homogeneity as judged by SDS-PAGE. Figure S2. Relative positions of residue 162 and residue 392 in CSFV and BVDV NS5B confirmation displayed by VMD software based on previous reports [31,35]. Residue 162 (red) and residue392 (orange) were marked in the structures. The fingertip region contains the $\mathrm{N}$-terminal part of the finger domain (yellow) and the insertion in the $\beta$-finger domain (violet). The fingertip bridges the finger domain and thumb domain (green). Residue 162 is located at the C-terminal of one part (yellow) of the fingertip region, and residue 392 is located at the tip of the middle finger close to residue 162 . The accession codes of CSFV and BVDV NS5B in the Protein Data Bank, respectively, are 5Y6R and $1 \mathrm{~S} 48[31,35]$. Table S1. Analysis of two CSFV C strains based on amino acid sequences.

Author Contributions: Conceptualization, Z.P.; methodology, H.P. and L.L.; investigation, H.P., H.L. and L.L.; data curation, Z.P. and H.P.; writing—original draft preparation, H.P.; writing—review and editing, Z.P.; visualization, H.P. and Z.P.; supervision, Z.P.; funding acquisition, Z.P. All authors have read and agreed to the published version of the manuscript.

Funding: This research was funded by the National Key Research and Development Program of China (2018YFD0500104), the National Natural Science Foundation of China (31670154).

Institutional Review Board Statement: Not applicable.

Informed Consent Statement: Not applicable.

Data Availability Statement: The data presented in this study are available on request from the corresponding author.

Acknowledgments: We thank Peng Gong and Weichi Liu for providing the T30 template and the GG dinucleotide, technical support and helpful discussions.

Conflicts of Interest: The authors declare no conflict of interest.

\section{References}

1. Becher, P.; Avalos Ramirez, R.; Orlich, M.; Cedillo Rosales, S.; Konig, M.; Schweizer, M.; Stalder, H.; Schirrmeier, H.; Thiel, H.J. Genetic and antigenic characterization of novel pestivirus genotypes: Implications for classification. Virology 2003, 311, 96-104. [CrossRef]

2. Becher, P.; Thiel, H.-J. Pestivirus. In The Springer Index of Viruses; Tidona, C.A., Darai, G., Büchen-Osmond, C., Eds.; Springer: Berlin/Heidelberg, Germany, 2001; pp. 327-331. [CrossRef]

3. Collett, M.S.; Moennig, V.; Horzinek, M.C. Recent advances in pestivirus research. J. Gen. Virol. 1989, 70 Pt 2, 253-266. [CrossRef]

4. Lamp, B.; Riedel, C.; Roman-Sosa, G.; Heimann, M.; Jacobi, S.; Becher, P.; Thiel, H.J.; Rumenapf, T. Biosynthesis of classical swine fever virus nonstructural proteins. J. Virol. 2011, 85, 3607-3620. [CrossRef]

5. Rumenapf, T.; Unger, G.; Strauss, J.H.; Thiel, H.J. Processing of the envelope glycoproteins of pestiviruses. J. Virol. 1993, 67, 3288-3294. [CrossRef] [PubMed]

6. Thiel, H.J.; Stark, R.; Weiland, E.; Rumenapf, T.; Meyers, G. Hog cholera virus: Molecular composition of virions from a pestivirus. J. Virol. 1991, 65, 4705-4712. [CrossRef] [PubMed]

7. Qiu, H.J.; Tong, G.Z.; Shen, R.X. The lapinized Chinese strain of classical swine fever virus: A retrospective review spanning half a century. Agric. Sci. China 2006, 5, 1-14. [CrossRef]

8. Xia, H.; Wahlberg, N.; Qiu, H.J.; Widén, F.; Belák, S.; Liu, L. Lack of phylogenetic evidence that the Shimen strain is the parental strain of the lapinized Chinese strain (C-strain) vaccine against classical swine fever. Arch. Virol. 2011, 156, 1041-1044. [CrossRef] [PubMed]

9. Li, C.; Li, Y.; Shen, L.; Huang, J.; Sun, Y.; Luo, Y.; Zhao, B.; Wang, C.; Yuan, J.; Qiu, H.J. The role of noncoding regions of classical swine fever virus C-strain in its adaptation to the rabbit. Virus Res. 2014, 183, 117-122. [CrossRef]

10. Graham, S.P.; Everett, H.E.; Haines, F.J.; Johns, H.L.; Sosan, O.A.; Salguero, F.J.; Clifford, D.J.; Steinbach, F.; Drew, T.W.; Crooke, H.R. Challenge of pigs with classical swine fever viruses after C-strain vaccination reveals remarkably rapid protection and insights into early immunity. PLoS ONE 2012, 7, e29310. [CrossRef] 
11. Suradhat, S.; Damrongwatanapokin, S. The influence of maternal immunity on the efficacy of a classical swine fever vaccine against classical swine fever virus, genogroup 2.2, infection. Vet. Microbiol. 2003, 92, 187-194. [CrossRef]

12. Vandeputte, J.; Too, H.L.; Ng, F.K.; Chen, C.; Chai, K.K.; Liao, G.A. Adsorption of colostral antibodies against classical swine fever, persistence of maternal antibodies, and effect on response to vaccination in baby pigs. Am. J. Vet. Res. 2001, 62, 1805-1811. [CrossRef]

13. Xiao, M.; Gao, J.; Wang, Y.; Wang, X.; Lu, W.; Zhen, Y.; Chen, J.; Li, B. Influence of a 12-nt insertion present in the $3^{\prime}$ untranslated region of classical swine fever virus HCLV strain genome on RNA synthesis. Virus Res. 2004, 102, 191-198. [CrossRef] [PubMed]

14. Fletcher, S.P.; Jackson, R.J. Pestivirus internal ribosome entry site (IRES) structure and function: Elements in the $5^{\prime}$ untranslated region important for IRES function. J. Virol. 2002, 76, 5024-5033. [CrossRef] [PubMed]

15. Sheng, C.; Chen, Y.; Xiao, J.; Xiao, J.; Wang, J.; Li, G.; Chen, J.; Xiao, M. Classical swine fever virus NS5A protein interacts with 3'-untranslated region and regulates viral RNA synthesis. Virus Res. 2012, 163, 636-643. [CrossRef] [PubMed]

16. Yu, H.; Grassmann, C.W.; Behrens, S.E. Sequence and structural elements at the $3^{\prime}$ terminus of bovine viral diarrhea virus genomic RNA: Functional role during RNA replication. J. Virol. 1999, 73, 3638-3648. [CrossRef] [PubMed]

17. Xiao, M.; Zhang, C.Y.; Pan, Z.S.; Wu, H.X.; Guo, J.Q. Classical swine fever virus NS5B-GFP fusion protein possesses an RNAdependent RNA polymerase activity. Arch. Virol. 2002, 147, 1779-1787. [CrossRef]

18. Xiao, M.; Gao, J.; Wang, W.; Wang, Y.; Chen, J.; Chen, J.; Li, B. Specific interaction between the classical swine fever virus NS5B protein and the viral genome. Eur. J. Biochem. 2004, 271, 3888-3896. [CrossRef]

19. Pankraz, A.; Thiel, H.J.; Becher, P. Essential and nonessential elements in the $3^{\prime}$ nontranslated region of Bovine viral diarrhea virus. J. Virol. 2005, 79, 9119-9127. [CrossRef]

20. Wu, H.X.; Wang, J.F.; Zhang, C.Y.; Fu, L.Z.; Pan, Z.S.; Wang, N.; Zhang, P.W.; Zhao, W.G. Attenuated lapinized chinese strain of classical swine fever virus: Complete nucleotide sequence and character of 3'-noncoding region. Virus Genes 2001, 23, 69-76. [CrossRef]

21. Bjorklund, H.V.; Stadejek, T.; Vilcek, S.; Belak, S. Molecular characterization of the $3^{\prime}$ noncoding region of classical swine fever virus vaccine strains. Virus Genes 1998, 16, 307-312. [CrossRef]

22. Wang, Y.; Wang, Q.; Lu, X.; Zhang, C.; Fan, X.; Pan, Z.; Xu, L.; Wen, G.; Ning, Y.; Tang, F.; et al. 12-nt insertion in 3' untranslated region leads to attenuation of classic swine fever virus and protects host against lethal challenge. Virology 2008, 374, 390-398. [CrossRef]

23. Behrens, S.E.; Tomei, L.; De Francesco, R. Identification and properties of the RNA-dependent RNA polymerase of hepatitis C virus. EMBO J. 1996, 15, 12-22. [CrossRef]

24. Zhong, W.; Gutshall, L.L.; Del Vecchio, A.M. Identification and characterization of an RNA-dependent RNA polymerase activity within the nonstructural protein 5B region of bovine viral diarrhea virus. J. Virol. 1998, 72, 9365-9369. [CrossRef]

25. Zhong, W.; Uss, A.S.; Ferrari, E.; Lau, J.Y.; Hong, Z. De novo initiation of RNA synthesis by hepatitis C virus nonstructural protein 5B polymerase. J. Virol. 2000, 74, 2017-2022. [CrossRef]

26. Kao, C.C.; Singh, P.; Ecker, D.J. De novo initiation of viral RNA-dependent RNA synthesis. Virology 2001, 287, 251-260. [CrossRef]

27. Appleby, T.C.; Perry, J.K.; Murakami, E.; Barauskas, O.; Feng, J.; Cho, A.; Fox, D., 3rd; Wetmore, D.R.; McGrath, M.E.; Ray, A.S.; et al. Viral replication. Structural basis for RNA replication by the hepatitis C virus polymerase. Science 2015, 347, 771-775. [CrossRef]

28. Dutartre, H.; Boretto, J.; Guillemot, J.C.; Canard, B. A relaxed discrimination of 2'-O-methyl-GTP relative to GTP between de novo and Elongative RNA synthesis by the hepatitis C RNA-dependent RNA polymerase NS5B. J. Biol. Chem. 2005, 280, 6359-6368. [CrossRef]

29. Scrima, N.; Caillet-Saguy, C.; Ventura, M.; Harrus, D.; Astier-Gin, T.; Bressanelli, S. Two crucial early steps in RNA synthesis by the hepatitis $C$ virus polymerase involve a dual role of residue 405. J. Virol. 2012, 86, 7107-7117. [CrossRef] [PubMed]

30. Liu, W.; Shi, X.; Gong, P. A unique intra-molecular fidelity-modulating mechanism identified in a viral RNA-dependent RNA polymerase. Nucleic Acids Res. 2018, 46, 10840-10854. [CrossRef] [PubMed]

31. Li, W.; Wu, B.; Soca, W.A.; An, L. Crystal Structure of Classical Swine Fever Virus NS5B Reveals a Novel N-Terminal Domain. J. Virol. 2018, 92, e00324-18. [CrossRef] [PubMed]

32. Steffens, S.; Thiel, H.J.; Behrens, S.E. The RNA-dependent RNA polymerases of different members of the family Flaviviridae exhibit similar properties in vitro. J. Gen. Virol. 1999, 80 Pt 10, 2583-2590. [CrossRef]

33. Wang, Y.; Xiao, M.; Chen, J.; Zhang, W.; Luo, J.; Bao, K.; Nie, M.; Chen, J.; Li, B. Mutational analysis of the GDD sequence motif of classical swine fever virus RNA-dependent RNA polymerases. Virus Genes 2007, 34, 63-65. [CrossRef]

34. Choi, K.H.; Gallei, A.; Becher, P.; Rossmann, M.G. The structure of bovine viral diarrhea virus RNA-dependent RNA polymerase and its amino-terminal domain. Structure 2006, 14, 1107-1113. [CrossRef]

35. Choi, K.H.; Groarke, J.M.; Young, D.C.; Kuhn, R.J.; Smith, J.L.; Pevear, D.C.; Rossmann, M.G. The structure of the RNA-dependent RNA polymerase from bovine viral diarrhea virus establishes the role of GTP in de novo initiation. Proc. Natl. Acad. Sci. USA 2004, 101, 4425-4430. [CrossRef] [PubMed]

36. Li, L.; Pang, H.; Wu, R.; Zhang, Y.; Tan, Y.; Pan, Z. Development of a novel single-step reverse genetics system for the generation of classical swine fever virus. Arch. Virol. 2016, 161, 1831-1838. [CrossRef]

37. Reed, L.J.; Muench, H. A simple method for estimating fifty percent end points. Am. J. Hyg. 1938, $27,493-497$. 
38. Wu, R.; Li, L.; Zhao, Y.; Tu, J.; Pan, Z. Identification of two amino acids within E2 important for the pathogenicity of chimeric classical swine fever virus. Virus Res. 2016, 211, 79-85. [CrossRef] [PubMed]

39. Yang, Z.; Wu, R.; Li, R.W.; Li, L.; Xiong, Z.; Zhao, H.; Guo, D.; Pan, Z. Chimeric classical swine fever (CSF)-Japanese encephalitis (JE) viral replicon as a non-transmissible vaccine candidate against CSF and JE infections. Virus Res. 2012, 165, 61-70. [CrossRef] [PubMed]

40. Tong, C.; Chen, N.; Liao, X.; Yuan, X.; Sun, M.; Li, X.; Fang, W. Continuous Passaging of a Recombinant C-Strain Virus in PK-15 Cells Selects Culture-Adapted Variants that Showed Enhanced Replication but Failed to Induce Fever in Rabbits. J. Microbiol. Biotechnol. 2017, 27, 1701. [CrossRef]

41. Li, L.; Wu, R.; Zheng, F.; Zhao, C.; Pan, Z. The N-terminus of classical swine fever virus (CSFV) nonstructural protein 2 modulates viral genome RNA replication. Virus Res. 2015, 210, 90-99. [CrossRef]

42. Zheng, L.; Baumann, U.; Reymond, J.L. An efficient one-step site-directed and site-saturation mutagenesis protocol. Nucleic Acids Res. 2004, 32, e115. [CrossRef]

43. Xie, L.; Han, Y.; Ma, Y.; Yuan, M.; Li, W.; Li, L.F.; Li, M.; Sun, Y.; Luo, Y.; Li, S.; et al. P108 and T109 on E2 Glycoprotein Domain I Are Critical for the Adaptation of Classical Swine Fever Virus to Rabbits but Not for Virulence in Pigs. J. Virol. 2020, 94, e01104-20. [CrossRef] [PubMed]

44. Hoffmann, B.; Beer, M.; Schelp, C.; Schirrmeier, H.; Depner, K. Validation of a real-time RT-PCR assay for sensitive and specific detection of classical swine fever. J. Virol. Methods 2005, 130, 36-44. [CrossRef]

45. Curti, E.; Jaeger, J. Residues Arg283, Arg285, and Ile287 in the nucleotide binding pocket of bovine viral diarrhea virus NS5B RNA polymerase affect catalysis and fidelity. J. Virol. 2013, 87, 199-207. [CrossRef]

46. Wen, G.; Xue, J.; Shen, Y.; Zhang, C.; Pan, Z. Characterization of classical swine fever virus (CSFV) nonstructural protein 3 (NS3) helicase activity and its modulation by CSFV RNA-dependent RNA polymerase. Virus Res. 2009, 141, 63-70. [CrossRef]

47. Wu, J.; Ye, H.Q.; Zhang, Q.Y.; Lu, G.; Zhang, B.; Gong, P. A conformation-based intra-molecular initiation factor identified in the flavivirus RNA-dependent RNA polymerase. PLoS Pathog. 2020, 16, e1008484. [CrossRef] [PubMed]

48. Wu, J.; Lu, G.; Zhang, B.; Gong, P. Perturbation in the conserved methyltransferase-polymerase interface of flavivirus NS5 differentially affects polymerase initiation and elongation. J. Virol. 2015, 89, 249-261. [CrossRef] [PubMed]

49. Kamkaew, M.; Chimnaronk, S. Characterization of soluble RNA-dependent RNA polymerase from dengue virus serotype 2: The polyhistidine tag compromises the polymerase activity. Protein Expr. Purif. 2015, 112, 43-49. [CrossRef] [PubMed]

50. Nguyen, H.T.; Chong, Y.; Oh, D.K.; Heo, Y.S.; Viet, P.T.; Kang, L.W.; Jeon, S.J.; Kim, D.E. An efficient colorimetric assay for RNA synthesis by viral RNA-dependent RNA polymerases, using thermostable pyrophosphatase. Anal. Biochem. 2013, 434, 284-286. [CrossRef] [PubMed]

51. de Smit, A.J.; van Gennip, H.G.; Miedema, G.K.; van Rijn, P.A.; Terpstra, C.; Moormann, R.J. Recombinant classical swine fever (CSF) viruses derived from the Chinese vaccine strain (C-strain) of CSF virus retain their avirulent and immunogenic characteristics. Vaccine 2000, 18, 2351-2358. [CrossRef]

52. Jin, Z.; Leveque, V.; Ma, H.; Johnson, K.A.; Klumpp, K. Assembly, purification, and pre-steady-state kinetic analysis of active RNA-dependent RNA polymerase elongation complex. J. Biol. Chem. 2012, 287, 10674-10683. [CrossRef]

53. Hobdey, S.E.; Kempf, B.J.; Steil, B.P.; Barton, D.J.; Peersen, O.B. Poliovirus polymerase residue 5 plays a critical role in elongation complex stability. J. Virol. 2010, 84, 8072-8084. [CrossRef] [PubMed]

54. Ganges, L.; Crooke, H.R.; Bohorquez, J.A.; Postel, A.; Sakoda, Y.; Becher, P.; Ruggli, N. Classical swine fever virus: The past, present and future. Virus Res. 2020, 289, 198151. [CrossRef]

55. Reimann, I.; Depner, K.; Trapp, S.; Beer, M. An avirulent chimeric Pestivirus with altered cell tropism protects pigs against lethal infection with classical swine fever virus. Virology 2004, 322, 143-157. [CrossRef]

56. van Gennip, H.G.; van Rijn, P.A.; Widjojoatmodjo, M.N.; de Smit, A.J.; Moormann, R.J. Chimeric classical swine fever viruses containing envelope protein $\mathrm{E}(\mathrm{RNS})$ or $\mathrm{E} 2$ of bovine viral diarrhoea virus protect pigs against challenge with CSFV and induce a distinguishable antibody response. Vaccine 2000, 19, 447-459. [CrossRef]

57. Hofmann, M.A. Construction of an infectious chimeric classical swine fever virus containing the $5^{\prime} \mathrm{UTR}$ of bovine viral diarrhea virus, and its application as a universal internal positive control in real-time RT-PCR. J. Virol. Methods 2003, 114, 77-90. [CrossRef] [PubMed]

58. Deng, R.; Brock, K.V. $5^{\prime}$ and $3^{\prime}$ untranslated regions of pestivirus genome: Primary and secondary structure analyses. Nucleic Acids Res. 1993, 21, 1949-1957. [CrossRef] [PubMed]

59. Zuker, M. Mfold web server for nucleic acid folding and hybridization prediction. Nucleic Acids Res. 2003, 31, 3406-3415. [CrossRef] [PubMed]

60. Van Gennip, H.G.; Vlot, A.C.; Hulst, M.M.; De Smit, A.J.; Moormann, R.J. Determinants of virulence of classical swine fever virus strain Brescia. J. Virol. 2004, 78, 8812-8823. [CrossRef]

61. Hulst, M.M.; van Gennip, H.G.; Moormann, R.J. Passage of classical swine fever virus in cultured swine kidney cells selects virus variants that bind to heparan sulfate due to a single amino acid change in envelope protein E(rns). J. Virol. 2000, 74, 9553-9561. [CrossRef]

62. Cao, T.; Zhang, S.; Li, X.; Xu, Y.; Wang, Z.; Chen, C.; Paudyal, N.; Li, X.; Sun, J.; Fang, W. Classical swine fever virus C-strain with eight mutation sites shows enhanced cell adaptation and protects pigs from lethal challenge. Arch. Virol. 2019, 164, 1619-1628. [CrossRef] 
63. Li, Y.; Xie, L.; Zhang, L.; Wang, X.; Li, C.; Han, Y.; Hu, S.; Sun, Y.; Li, S.; Luo, Y.; et al. The E2 glycoprotein is necessary but not sufficient for the adaptation of classical swine fever virus lapinized vaccine C-strain to the rabbit. Virology 2018, 519, 197-206. [CrossRef] [PubMed]

64. Cao, T.; Wang, Z.; Li, X.; Zhang, S.; Paudyal, N.; Zhang, X.; Li, X.; Fang, W. E2 and E(rns) of classical swine fever virus C-strain play central roles in its adaptation to rabbits. Virus Genes 2019, 55, 238-242. [CrossRef] [PubMed]

65. Xiao, M.; Li, H.; Wang, Y.; Wang, X.; Wang, W.; Peng, J.; Chen, J.; Li, B. Characterization of the N-terminal domain of classical swine fever virus RNA-dependent RNA polymerase. J. Gen. Virol. 2006, 87, 347-356. [CrossRef] [PubMed]

66. Lesburg, C.A.; Cable, M.B.; Ferrari, E.; Hong, Z.; Mannarino, A.F.; Weber, P.C. Crystal structure of the RNA-dependent RNA polymerase from hepatitis C virus reveals a fully encircled active site. Nat. Struct. Biol. 1999, 6, 937-943. [CrossRef] [PubMed]

67. Zhang, P.; Xie, J.; Yi, G.; Zhang, C.; Zhou, R. De novo RNA synthesis and homology modeling of the classical swine fever virus RNA polymerase. Virus Res. 2005, 112, 9-23. [CrossRef]

68. Di Marco, S.; Volpari, C.; Tomei, L.; Altamura, S.; Harper, S.; Narjes, F.; Koch, U.; Rowley, M.; De Francesco, R.; Migliaccio, G.; et al. Interdomain communication in hepatitis $\mathrm{C}$ virus polymerase abolished by small molecule inhibitors bound to a novel allosteric site. J. Biol. Chem. 2005, 280, 29765-29770. [CrossRef]

69. O'Farrell, D.; Trowbridge, R.; Rowlands, D.; Jager, J. Substrate complexes of hepatitis C virus RNA polymerase (HC-J4): Structural evidence for nucleotide import and de-novo initiation. J. Mol. Biol. 2003, 326, 1025-1035. [CrossRef]

70. Butcher, S.J.; Grimes, J.M.; Makeyev, E.V.; Bamford, D.H.; Stuart, D.I. A mechanism for initiating RNA-dependent RNA polymerization. Nature 2001, 410, 235-240. [CrossRef] [PubMed]

71. Kim, Y.C.; Russell, W.K.; Ranjith-Kumar, C.T.; Thomson, M.; Russell, D.H.; Kao, C.C. Functional analysis of RNA binding by the hepatitis C virus RNA-dependent RNA polymerase. J. Biol. Chem. 2005, 280, 38011-38019. [CrossRef] [PubMed]

72. Wu, R.; Li, L.; Lei, L.; Zhao, C.; Shen, X.; Zhao, H.; Pan, Z. Synergistic roles of the E2 glycoprotein and $3^{\prime}$ untranslated region in the increased genomic stability of chimeric classical swine fever virus with attenuated phenotypes. Arch. Virol. 2017, 162, 2667-2678. [CrossRef] [PubMed] 